ARTICLE

\title{
A source of isotopically light organic carbon in a low-pH anoxic marine zone
}

\author{
Cristian A. Vargas (10) 1,2,3凶 , Sebastian I. Cantarero ${ }^{4}$, Julio Sepúlveda ${ }^{2,4}$, Alexander Galán ${ }^{5,6}$, \\ Ricardo De Pol-Holz (D) ${ }^{7}$, Brett Walker (D) ${ }^{8}$, Wolfgang Schneider ${ }^{2,9}$, Laura Farías $3,9,10$, \\ Marcela Cornejo D'Ottone ${ }^{2,11}$, Jennifer Walker ${ }^{12}$, Xiaomei Xu (iD) ${ }^{12} \&$ Joe Salisbury ${ }^{13}$
}

Geochemical and stable isotope measurements in the anoxic marine zone (AMZ) off northern Chile during periods of contrasting oceanographic conditions indicate that microbial processes mediating sulfur and nitrogen cycling exert a significant control on the carbonate chemistry ( $\mathrm{pH}, \mathrm{A}_{\mathrm{T}}, \mathrm{DIC}$ and $p \mathrm{CO}_{2}$ ) of this region. Here we show that in 2015, a large isotopic fractionation between DIC and POC, a DIC and N deficit in AMZ waters indicate the predominance of in situ dark carbon fixation by sulfur-driven autotrophic denitrification in addition to anammox. In 2018, however, the fractionation between DIC and POC was significantly lower, while the total alkalinity increased in the low-pH AMZ core, suggesting a predominance of heterotrophic processes. An isotope mass-balance model demonstrates that variations in the rates of sulfur- and nitrogen-mediated carbon fixation in AMZ waters contribute $\sim 7-35 \%$ of the POC exported to deeper waters. Thus, dark carbon fixation should be included in assessments of future changes in carbon cycling and carbonate chemistry due to $\mathrm{AMZ}$ expansion.

\footnotetext{
${ }^{1}$ Department of Aquatic System, Faculty of Environmental Sciences \& Environmental Sciences Center EULA Chile, Universidad de Concepción, Concepción, Chile. ${ }^{2}$ Millennium Institute of Oceanography (IMO), Universidad de Concepción, Concepción, Chile. ${ }^{3}$ Coastal Social-Ecological Millennium Institute (SECOS), Universidad de Concepción, Concepción, Chile. ${ }^{4}$ Department of Geological Sciences and Institute of Arctic and Alpine Research (INSTAAR), University of Colorado Boulder, Boulder, CO, USA. ${ }^{5}$ Centro de Investigación de Estudios Avanzados del Maule (CIEAM), Departamento de Obras Civiles, Facultad de Ciencias de la Ingeniería, Universidad Católica del Maule, Talca, Chile. ${ }^{6}$ Centro Regional de Estudios Ambientales (CREA), Universidad Católica de la Santísima Concepción, Concepción, Chile. ${ }^{7}$ Centro de Investigación GAIA-Antártica (CIGA) and Network for Extreme Environment Research (NEXER), Universidad de Magallanes, Punta Arenas, Chile. ${ }^{8}$ Department of Earth and Environmental Sciences, University of Ottawa, Ottawa, Canada. ${ }^{9}$ Department of Oceanography, Universidad de Concepcion, Concepcion, Chile. ${ }^{10}$ Center for Climate and Resilience Research (CR)2, Santiago, Chile. ${ }^{11}$ Escuela de Ciencias del Mar, P. Universidad Católica de Valparaíso, Valparaíso, Chile. ${ }^{12}$ Department of Earth System Science, University of California, Irvine, CA, USA. ${ }^{13}$ Ocean Process Analysis Lab, University of New Hampshire, Durham, NC, USA. ${ }^{凶}$ email: crvargas@udec.cl
} 
D issolved oxygen plays a key role in shaping the structure of marine ecosystems, the spatial and temporal distribution of marine organisms ${ }^{1}$, and regulates both metabolic and biogeochemical processes ${ }^{2}$. Since oxygen $\left(\mathrm{O}_{2}\right)$ is slowly depleted in the ocean with depth, in some regions this leads to the formation of steady-state $\mathrm{O}_{2}$-deficient intermediate layers commonly known as oxygen minimum zones $(\mathrm{OMZs})^{3,4} \cdot \mathrm{O}_{2}$ varies geographically among OMZs, but it generally falls below $<20 \mu \mathrm{mol} \mathrm{kg}-15$. Marine time series indicate a substantial shoaling of the upper OMZ boundary over the past decades along several eastern boundary-current systems, such as the Subarctic Pacific ${ }^{6}$, the eastern equatorial region, and the northeast Pacific Ocean ${ }^{8}$. Notably, newly developed oxygen sensors ${ }^{9}$ have demonstrated that $\mathrm{O}_{2}$ can fall below sensor-specific detection limits $\left(\sim 3 \mathrm{nmol} \mathrm{L}^{-1}\right)$ within a significant fraction of $\mathrm{OMZ}$ waters.

Due to their extreme oxygen-depletion, OMZs like the one along the eastern tropical South Pacific (ETSP) coast off Peru and Chile have been recently redefined as anoxic marine zones $(\mathrm{AMZs})^{10}$. AMZs are often distinguished from OMZs by the accumulation of nitrite, which typically occurs when $\mathrm{O}_{2}$ falls below the nanomolar detection limit ${ }^{10}$. In these anoxic zones, nitrate- and sulfate-reducing bacteria, as well as methanotrophic and canonical denitrifying bacteria dominate heterotrophic processes ${ }^{10,11}$. The combination of microbially mediated remineralization process, which consumes $\mathrm{O}_{2}$ and produces dissolved inorganic carbon (DIC), in addition to weak ventilation, leads to the establishment and persistence of $\mathrm{O}_{2}$-depleted waters. Organic carbon oxidation in AMZ waters is driven by microorganisms able to utilize alternative electron acceptors, which results in excess $\mathrm{CO}_{2}$ and lower $\mathrm{pH}(<7.8)^{12}$. Additionally, under such $\mathrm{O}_{2^{-}}$ limited conditions, chemolithoautotrophic processes that consume DIC are dominated by bacterial sulfur-driven autotrophic denitrification (SDAD) and anaerobic ammonium oxidation (Anammox), although oxygen-dependent nitrifying microorganisms (i.e., ammonium- and nitrite-oxidizers) also operate, but at lower rates ${ }^{13,14}$. In consequence, heterotrophic and chemoautotrophic processes associated with AMZs influence marine carbon dynamics and the cycling of key elements for marine productivity, but also the carbonate chemistry ( $\mathrm{pH}, \mathrm{DIC}$, and $p \mathrm{CO}_{2}$ ). The latter has been scarcely studied in these regions. For instance, heterotrophic activity reduces the efficiency of the biological carbon pump by consuming organic matter and releasing $\mathrm{CO}_{2}$, whereas chemoautotrophic processes can increase the efficiency of this pumping by fixing additional $\mathrm{CO}_{2}$ and generating new organic carbon in intermediate waters ${ }^{12,15}$.

Recent work has shown that the nitrite-rich AMZ in the ETSP off northern Chile is an extreme end-member within the spectrum of AMZ ecosystems, where $\mathrm{O}_{2}$ is mostly absent, except during sporadic intrusions ${ }^{10}$. Gene surveys in this region have shown that significant fractions of picoplankton in AMZ waters are chemoautotrophs associated with the cycling of sulfur and nitrogen, such as SDAD and anammox ${ }^{16,17}$. Furthermore, recent studies using isotope-mixing models in other AMZs also suggest that dark carbon fixation could contribute significantly to sinking carbon fluxes ${ }^{18}$. However, the influence of these chemoautotrophic processes on DIC and $p \mathrm{CO}_{2}$ levels in AMZ waters remains poorly understood. Since the biomass from chemoautotrophs inhabiting OMZs and AMZs is characterized by low $\delta^{13} \mathrm{C}$ signatures, which is modulated by both the uptake of remineralised and ${ }^{13} \mathrm{C}$-depleted $\mathrm{CO}_{2}{ }^{19}$, and the use of carbon fixation pathways such as the acetyl coenzyme $\mathrm{A}^{20}$, exported organic matter from these regions should preserve this isotopically depleted signature.

In view of the projected increases in both the extension and intensity of oxygen-deficient zones ${ }^{7,8}$, it remains crucial to improve our understanding about the natural variability in the carbonate chemistry system of AMZs to better predict future changes. Models suggest that a doubling of surface water $p \mathrm{CO}_{2}$ could lead to a doubling or more of $p \mathrm{CO}_{2}$ in OMZ/AMZ waters ${ }^{21}$, mostly due to the reduction of seawater's buffer capacity by the acidic components of the normal Redfield cycle ${ }^{22}$. However, these projections ignore the impact of microbially driven processes linked to sulfur and/or nitrogen on biogeochemical cycles, including carbon cycling. Moreover, modeling studies based on the oceanic uptake of anthropogenic $\mathrm{CO}_{2}$ indicate that surface waters in eastern boundary systems, such as the Humboldt Current, are likely to become more corrosive to $\mathrm{CaCO}_{3}{ }^{23}$. Nevertheless, the extent to which $\mathrm{O}_{2}$ concentrations, the sulfur and nitrogen cycles, and the carbonate system are linked in AMZs remains poorly understood ${ }^{12,15}$.

Here, by using a suite of physical (i.e. temperature, salinity) and chemical parameters (i.e., oxygen, inorganic nutrients, $\mathrm{pH}$, total alkalinity, carbon pool concentration, and their stable isotopic composition), we hypothesize that the unique microbial communities inhabiting the AMZ ecosystem of the ETSP off northern Chile ${ }^{10,17}$ constitute an important modulator of the carbonate chemistry variability in this region. These results are then incorporated into a simple carbon isotope box model to determine potential sources of organic matter and calculate the contribution of microbial autotrophic production in AMZ waters to organic carbon export to the mesopelagic region.

\section{Results}

Physical oceanographic conditions. During the second half of November 2015 (austral spring; early upwelling season), coastal upwelling started its seasonal intensification, as reflected in an upwelling index of $\sim 2000 \mathrm{~kg} \mathrm{~m}^{-1} \mathrm{~s}^{-1}$ off the coast of Iquique (Fig. 1c). Sea surface temperature was $\sim 21-22^{\circ} \mathrm{C}$, with a narrow upwelling signal $<19^{\circ} \mathrm{C}$ close to the coast (Fig. 1b). During early February 2018 (austral summer; upwelling peak) the upwelling index was $\sim 33 \%$ stronger $\left(3000 \mathrm{~kg} \mathrm{~m}^{-1} \mathrm{~s}^{-1}\right.$, Fig. 1e), whereas sea surface temperatures were as low as $17^{\circ} \mathrm{C}$ prevailed along the coast of northern Chile, including our coastal stations T1 and T2. These intense upwelling conditions were reflected in high surface chlorophyll a concentrations of about $20 \mathrm{mg} \mathrm{m}^{-3}$ within $50 \mathrm{~km}$ from the coastline, compared to lower concentrations of $5 \mathrm{mg} \mathrm{m}^{-3}$ in 2015 (Supplementary Fig. 1a, b). Another difference between the 2015 and 2018 cruises was the hydrographic properties of the upper thermocline. Unlike 2015, the water column in 2018 was characterized by the intrusion of well ventilated, low salinity water subducted off central Chile (Supplementary Fig. 1c) ${ }^{24}$. This water mass has a mean temperature of $12{ }^{\circ} \mathrm{C}$ and intrudes the upper pycnocline debilitating the AMZ, feeding the upwelling process during 2018. Anomalies of sea surface temperature for November and December 2015 did not indicate that the El Niño 2015/16 had yet arrived at the study area.

Carbon chemistry and C:N:P stoichiometry in the AMZ. During 2015, oxygen-deficient conditions $\left(<0.02 \mu \mathrm{mol} \mathrm{kg}^{-1}\right)$ were observed between steep upper $(\sim 80-100 \mathrm{~m})$ and lower $(\sim 400-450 \mathrm{~m})$ oxyclines along the coast off northern Chile $\left(20.0^{\circ}-29.5^{\circ} \mathrm{S}\right)$, as well as perpendicular to the coast across a neritic-pelagic transect off Iquique $\left(20^{\circ} \mathrm{S}\right.$; Fig. 2a). A nitrite maximum $\left(\mathrm{NO}_{2}^{-}>5 \mu \mathrm{mol} \mathrm{kg}-1\right.$ and up to $7.5 \mu \mathrm{mol} \mathrm{kg}{ }^{-1}$ ), characteristic of anoxic conditions, was detected in the core of the AMZ between 200 and $300 \mathrm{~m}$ depth along the coast from ca. $20^{\circ} \mathrm{S}$ to $26^{\circ} \mathrm{S}$ (Station L1-L4, Fig. 1b), as well as offshore from stations T4 to T6 (Fig. 2b). Below the AMZ core, $\mathrm{O}_{2}$ concentrations increased from under detection limit up to $80 \mu \mathrm{mol} \mathrm{kg}-1$ (Fig. 2a). Deficient $\mathrm{O}_{2}$ waters were also characterized by low $\mathrm{pH}$ ( 7.5-7.6) and high $p \mathrm{CO}_{2}(\sim 1200-1600 \mu \mathrm{atm})$ (Fig. 2d-f) compared to surface oxygenated waters ( $\mathrm{pH} 7.8-8.1$ and $\left.p \mathrm{CO}_{2} 400-700 \mu \mathrm{atm}\right)$. 

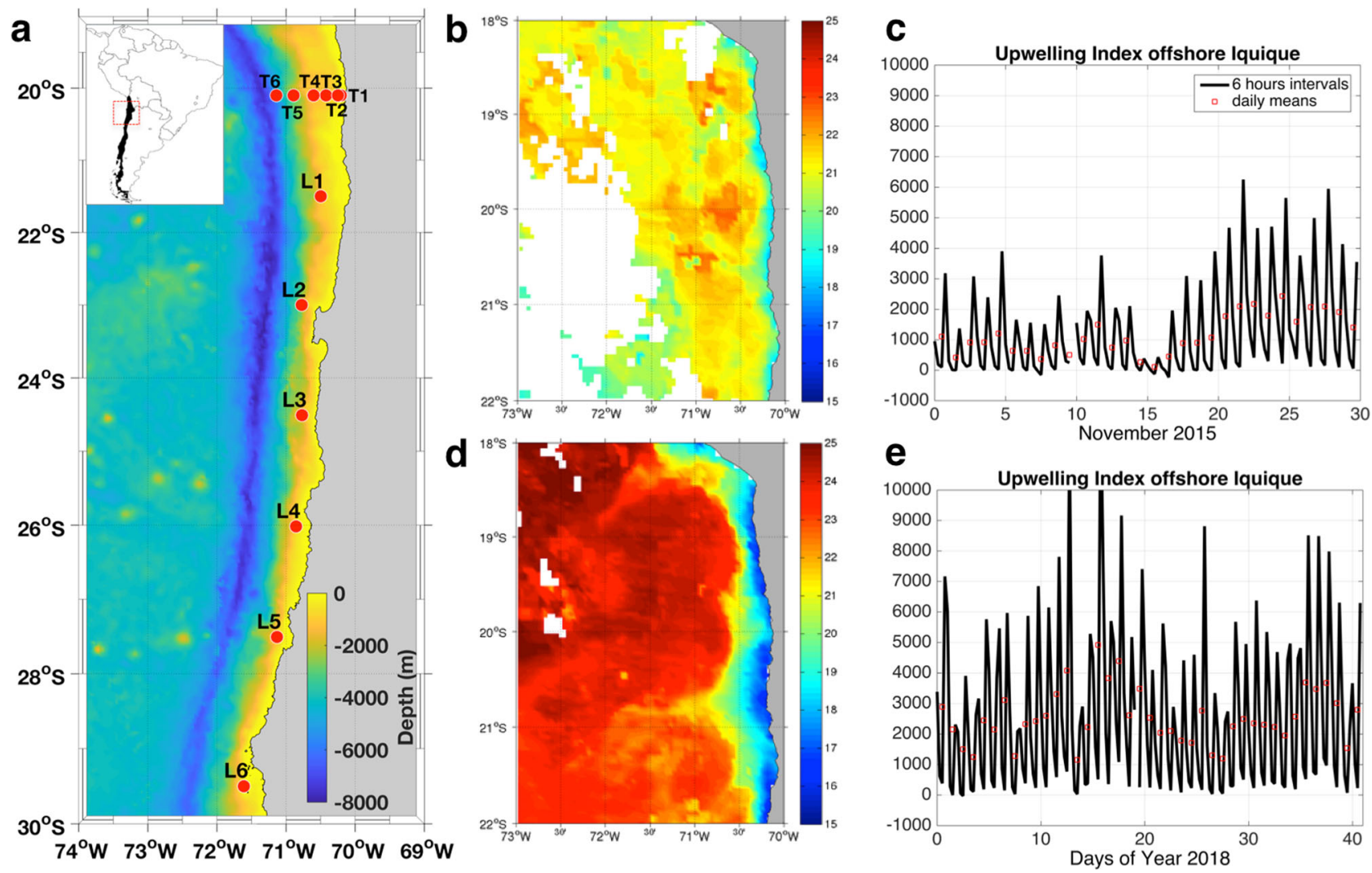

Fig. 1 Sampling stations and oceanographic conditions during the expeditions. a Study area, including six sampling stations ( $\mathrm{T} 1-\mathrm{T} 6$ ), and a longitudinal section from $20^{\circ}$ down to $29.5^{\circ} \mathrm{S}$, including six sampling stations (L1-L6). b 25 November-2 December 2015 composite of MODIS-Aqua SST for LowPhox I; units are in ${ }^{\circ} \mathrm{C}$; persisting clouds appear in white. c Upwelling Indices for the oceanic region offshore lquique for November 2015 ; black: 6-h intervals and red daily averages; units are in $\mathrm{kg} \mathrm{m}^{-1} \mathrm{~S}^{-1}$. d 2-9 February 2018 composite of MODIS-Agua SST for LowPhox II; units are in ${ }^{\circ} \mathrm{C}$; persisting clouds appear in white. e Upwelling index for the oceanic region offshore lquique from 1 January to 12 February 2018; the black lines are 6-h intervals and red dots correspond to daily averages; units are in $\mathrm{kg} \mathrm{m}^{-1} \mathrm{~s}^{-1}$.

In the $\mathrm{AMZ}$ core, the $\mathrm{DIC}$ and $p \mathrm{CO}_{2}$ were lower, whereas $\mathrm{pH}$ was comparatively higher in the $\mathrm{AMZ}$ core around the $\mathrm{NO}_{2}^{-}$maximum, compared to surrounding anoxic waters (e.g. see Stn L6, Fig. 2d, e).

A comparative analysis of seawater chemistry between 2015 and 2018 in the cross-shelf transect off Iquique (20 ${ }^{\circ} \mathrm{S}$; Stations T1-T6), evidenced highly contrasting conditions (Fig. 3). Whereas in 2015 the AMZ core (ca. $7.5 \mu \mathrm{mol} \mathrm{NO}{ }^{-} \mathrm{kg}^{-1}$ ) was deeper and located farther offshore, in 2018 the $\mathrm{NO}_{2}{ }^{-}$maximum $\left(<6.5 \mu \mathrm{mol} \mathrm{kg}{ }^{-1}\right)$ was slightly shallower and closer to the coast around Stn T3, whereas the slope of both $\mathrm{O}_{2}$ and $\mathrm{NO}_{2}{ }^{-}$isolines suggest the shoaling of low-oxygen waters over the continental shelf in 2018 (Fig. 3a-b, c-d). High DIC concentrations were observed in subsurface waters during 2015 ( $>2250 \mu \mathrm{mol} \mathrm{kg}^{-1}$; Fig. 3e), whereas in 2018 high DIC values were restricted to the continental shelf at Stn 1 (Fig. 3f). The relationship between DIC and $\mathrm{PO}_{4}{ }^{3-}$ concentration was relatively similar between both years as evidenced by similar slopes (Fig. 4a). However, during 2015, some regions of the oxygen-depleted waters showed low inorganic $\mathrm{N}$ content (i.e., $\mathrm{NO}_{3}{ }^{-}+\mathrm{NO}_{2}^{-}, \sim 20 \mu \mathrm{mol} \mathrm{kg}{ }^{-1}$ ) and a high $\mathrm{N}$ deficiency $\left(\mathrm{N}^{*} ;-10\right.$ to $\left.-20 \mu \mathrm{mol} \mathrm{kg}-1\right)$, associated with relatively lower DIC concentration (2160-2210 $\mathrm{mol} \mathrm{kg}^{-1}$ ) (Fig. 4b, c). As we discuss in more detail below, high $\mathrm{N}^{*}\left(>-10 \mu \mathrm{mol} \mathrm{kg}^{-1}\right)$ associated with increasing DIC $\left(\sim 2250 \mu \mathrm{mol} \mathrm{kg}{ }^{-1}\right)$ in low- $\mathrm{O}_{2}$ waters (filled blue dots in Fig. 4) appears to be related to denitrification; on the other hand, high $\mathrm{N}^{*}$ values at lower DIC concentration $\left(<2210 \mu \mathrm{mol} \mathrm{kg}^{-1}\right)$ in suboxic/anoxic conditions could be associated with both SDAD and anammox processes (Fig. $4 \mathrm{~b}, \mathrm{c}$ ). In fact, a decrease in DIC of up to $30 \mu \mathrm{mol}$ in the $\mathrm{AMZ}$ core suggests the prevalence of dark carbon fixation over heterotrophic denitrification in the DIC pool of some stations sampled during 2015 (Fig. 4b). Moreover, since both SDAD and anammox consume $\mathrm{H}^{+}$, the high $\mathrm{A}_{\mathrm{T}}\left(2310 \mu \mathrm{mol} \mathrm{kg}{ }^{-1}\right)$, which is likely related to the consumption of nitrate and nitrite, results in the more elevated $\mathrm{pH}(\sim 7.9)$ observed in oxygen-depleted waters (Stn 5) (Fig. 4d, e). Conversely, in 2018, we observed decreasing inorganic $\mathrm{N}$ and high $\mathrm{N}^{*}$, but with lower DIC concentrations and high $\mathrm{A}_{\mathrm{T}}$ in comparison to 2015 (filled red dots in Fig. 4b-d). Higher DIC concentration in the $\mathrm{AMZ}$ during 2015 resulted in lower $\mathrm{pH}_{\mathrm{T}}$ compared to 2018 (7.5-7.6 vs. 7.8-7.9, respectively; Fig. 4e). Indeed, the concentration of aqueous $\mathrm{CO}_{2}\left(\mathrm{CO}_{2 \text {-aq; }}\right.$; Supplementary Fig. 2a) in the $\mathrm{AMZ}$ core (i.e., $\mathrm{NO}_{2}^{-}$maximum) was significantly higher in $2015\left(\sim 50\right.$, and up to $\left.\sim 60 \mu \mathrm{mol} \mathrm{kg}{ }^{-1}\right)$ than in $2018(\sim 15$, and up to $\left.45 \mu \mathrm{mol} \mathrm{kg}{ }^{-1}\right)$. The relationship between $\mathrm{O}_{2}$ and $\mathrm{CO}_{2 \text {-aq }}$ in 2015 showed a large range of $\mathrm{CO}_{2 \text {-aq }}\left(25-60 \mu \mathrm{mol} \mathrm{kg}^{-1}\right)$ for waters with $<5 \mu \mathrm{mol} \mathrm{O} \mathrm{kg}^{-1}$, and $\mathrm{CO}_{2 \text {-aq }}$ values up to $10-15 \mu \mathrm{mol} \mathrm{kg}{ }^{-1}$ at the $\mathrm{NO}_{2}^{-}$maximum (5-7.5 $\mu \mathrm{mol} \mathrm{kg}{ }^{-1}$; Supplementary Fig. 2a).

During both years, suspended POC concentrations decreased by $15-20 \mu \mathrm{mol} \mathrm{kg} \mathrm{kg}^{-1}$ over the upper $100 \mathrm{~m}$ of the water column and remained low (ca. $5 \mu \mathrm{mol} \mathrm{kg}^{-1}$ ) through the OMZ (Fig. 3i, j). Contrasting concentration profiles between both years were also observed. In 2015, surface POC was $<18 \mu \mathrm{mol} \mathrm{kg}^{-1}$, whereas in 2018 it reached values up to $32 \mu \mathrm{mol} \mathrm{kg}{ }^{-1}$ (Fig. 3i, j). These trends were also reflected in chlorophyll-a concentrations, which exhibited lower $\left(<5 \mu \mathrm{gL}^{-1}\right)$ values in the coastal area (Stn T1 and T2) in 2015, whereas higher (up to $11.8 \mu \mathrm{g} \mathrm{L}^{-1}$ ) and more spatially distributed concentrations (from Stn T1 to T3) were observed in surface waters during 2018 (Supplementary Fig. 3). 
a

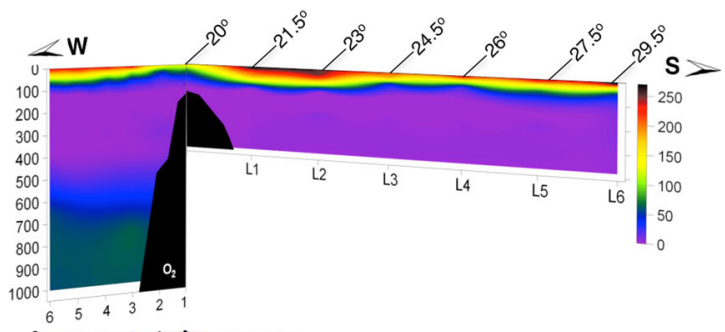

b

C

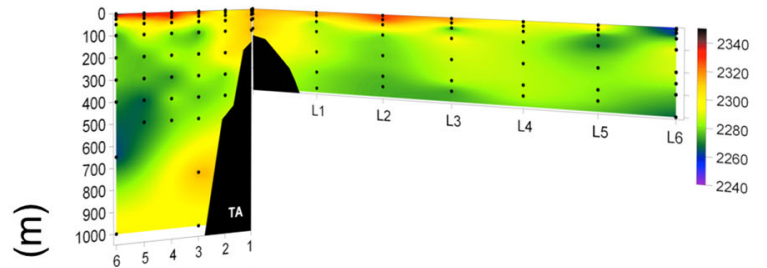

d

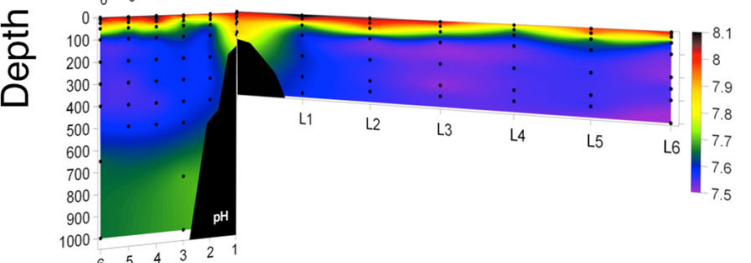

e

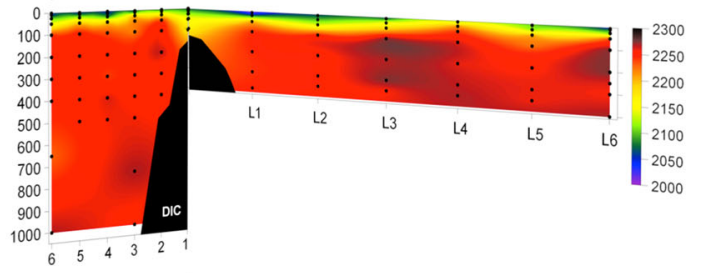

f

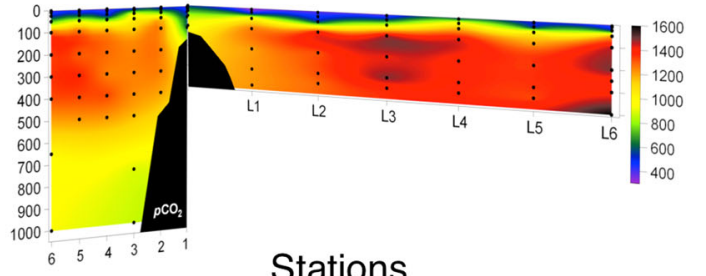

Fig. 2 Spatial variability in oxygen, nitrate, and carbonate chemistry during 2015. Vertical sections of (a) dissolved oxygen $\left(\mu \mathrm{mol} \mathrm{kg}{ }^{-1}\right)$, (b) nitrite $\left(\mu \mathrm{mol} \mathrm{kg}{ }^{-1}\right),(\mathbf{c})$ total alkalinity $(\mu \mathrm{mol} \mathrm{kg}-1),(\mathbf{d}) \mathrm{pH}_{\mathrm{T}},(\mathbf{e})$, dissolved inorganic carbon $\left(\mu \mathrm{mol} \mathrm{kg}{ }^{-1}\right.$ ), and $p \mathrm{CO}_{2}(\mu \mathrm{atm})$ during the research cruise in 2015. The sections included both a cross-shelf section at $20^{\circ} \mathrm{S}(1-6)$, and a latitudinal section along the coast (L1-L6). The black dots represent sample locations.

Isotopic signature of DIC and POC. The stable isotope composition of DIC and POC from the cross-shelf transect near Iquique $\left(20^{\circ} \mathrm{S}\right.$; Stations $\left.\mathrm{T} 1-6\right)$ showed contrasting conditions between both sampling periods (Fig. 3). In 2015, isotopically depleted $\delta^{13} \mathrm{C}_{\text {DIC }}$ values $(0.0$ to $-0.5 \%$ ) and high DIC concentrations $\left(>2250 \mu \mathrm{mol} \mathrm{kg}^{-1}\right)$ were observed within the AMZ, but particularly in the upper core region (e.g., Stn T3, 100-200 m; Fig. 3g). Isotopically depleted $\delta^{13} \mathrm{C}_{\text {DIC }}$ values were also observed at depth in 2018, but mostly associated with the coastal area (Stns $\mathrm{T} 1$ and T3), and between 100 and $400 \mathrm{~m}$ depth (Fig. 3h) along

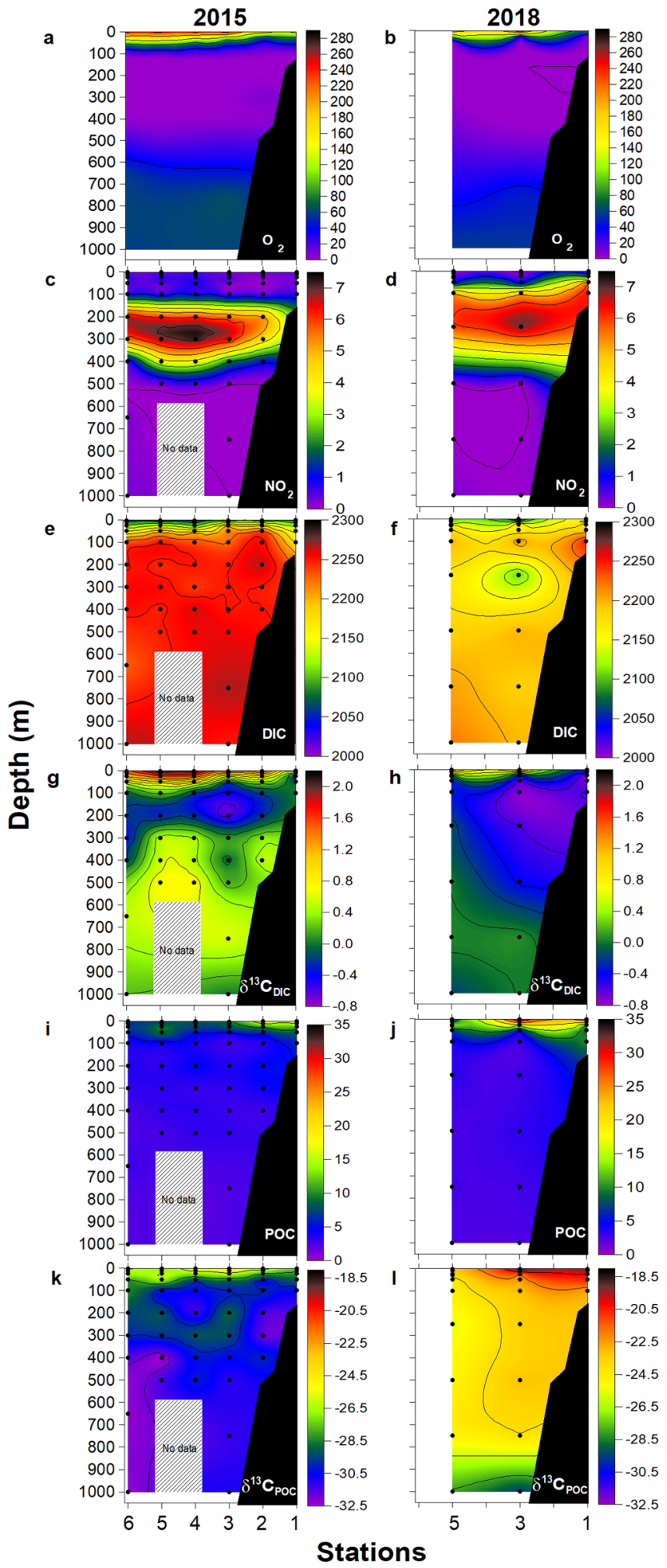

Fig. 3 Comparative conditions in 2015 vs. 2018 in a cross-shelf section off Iquique (20 $\left.{ }^{\circ} \mathbf{S}\right)$. Vertical cross-shelf sections of oxygen, nitrite, dissolved inorganic carbon (DIC) and particulate organic carbon (POC) pools and their ${ }^{13} \mathrm{C}$ isotopic values during research cruises in 2015 and 2018. (a, b) Dissolved oxygen $(\mu \mathrm{mol} \mathrm{kg}-1)$, (c, d) nitrite $(\mu \mathrm{mol} \mathrm{kg}-1),(\mathbf{e}, \mathbf{f})$ dissolved inorganic carbon $\left(\mu \mathrm{mol} \mathrm{kg}^{-1}\right),(\mathbf{g}, \mathbf{h}) \delta^{13} \mathrm{C}_{\mathrm{DIC}}(\% \mathrm{o}),(\mathbf{i}, \mathbf{j})$ particulate organic carbon $\left(\mu \mathrm{mol} \mathrm{kg}{ }^{-1}\right)$, and $(\mathbf{k}, \mathbf{I}) \delta^{13} C_{\text {POC }}(\% o)$. The black dots represent sample locations. Gray box represents area with noncollected data. 

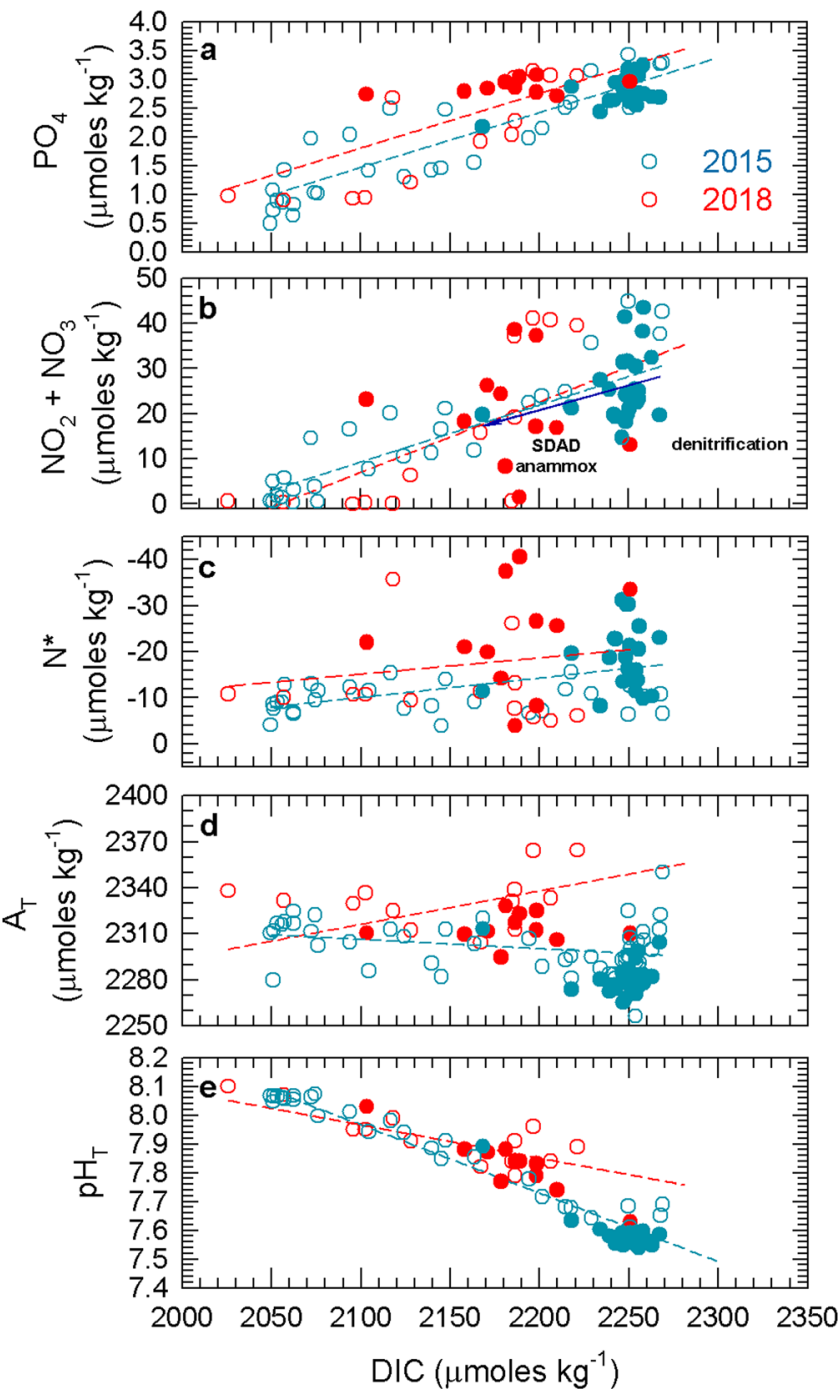

Fig. 4 Relationship between dissolved inorganic carbon (DIC) versus nutrients and other carbonate chemistry parameters. (a) $\mathrm{PO}_{4}{ }^{3-},($ b) inorganic nitrogen $\left(\mathrm{NO}_{2}{ }^{-}+\mathrm{NO}_{3}^{-}\right),(\mathbf{c}) \mathrm{N}^{*},(\mathbf{d})$ total $\mathrm{pH}\left(\mathrm{pH}_{\mathrm{T}}\right)$, and $(\mathbf{e})$ total alkalinity $\left(\mathrm{A}_{T}\right)$, within the range from surface to $1000 \mathrm{~m}$ water depth during 2015 and 2018 expeditions. Filled symbols correspond to data points associated with $\mathrm{O}_{2}$ concentrations $<20 \mu \mathrm{mol} \mathrm{kg}{ }^{-1}$. The correlations observed in low oxygen waters (filled points) for DIC versus nitrogen at 2015 is given and indicated by the dark blue line (b). Labels in (b) were included to emphasize the processes highlighted in the stoichiometric analysis (e.g. Annamox, sulfur-driven autotrophic denitrification (SDAD), and denitrification).

with the highest concentration of $\mathrm{NO}_{2}{ }^{-}$(Fig. 3d). During 2018, we observed even more isotopically depleted $\delta^{13} \mathrm{C}_{\text {DIC }}$ values $(-0.6$ to $-0.8 \%)$ and slightly lower, yet still high, DIC concentrations $\left(<2200 \mu \mathrm{mol} \mathrm{kg}^{-1}\right)$ compared to 2015 (Fig. 3g, h). The observed relationship between DIC concentration and $\delta^{13} \mathrm{C}_{\text {DIC }}$ (Supplementary Fig. $2 \mathrm{~b}$ ) suggests that $\delta^{13} \mathrm{C}_{\text {DIC }}$ is primarily governed by biological uptake in oxygenated waters $(>20 \mu \mathrm{mol} \mathrm{kg}-1)$ and by microbial respiration in low $\mathrm{O}_{2}$ waters $\left(<20 \mu \mathrm{mol} \mathrm{kg}{ }^{-1}\right)$, with the most depleted $\delta^{13} \mathrm{C}$ values associated with low oxygen and high $p \mathrm{CO}_{2}$ waters.

The difference in $\delta^{13} \mathrm{C}_{\mathrm{POC}}$ values between both years was larger than in $\delta^{13} \mathrm{C}_{\text {DIC }}$. The $\delta \delta^{13} \mathrm{C}_{\mathrm{POC}}$ in the upper $50 \mathrm{~m}$ ranged between $-23 \%$ and $-27 \%$ in 2015 and from $-18.5 \%$ to $-20.5 \%$ in 2018 , with the most positive $\delta^{13} C_{\text {POC }}$ values in the euphotic zone

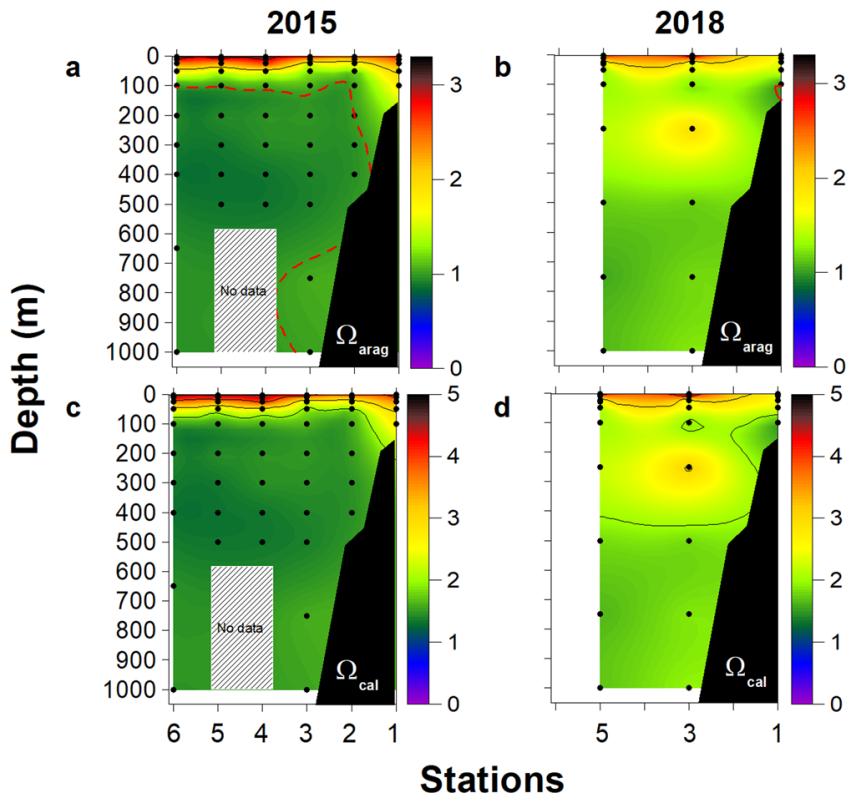

Fig. 5 Calcium carbonate saturation state during both research cruises. Vertical cross-shelf sections of $(\mathbf{a}, \mathbf{b})$ aragonite saturation state $\left(\Omega_{\text {arag }}\right)$ and (c, d) calcite saturation state $\left(\Omega_{\text {cal }}\right)$ during research cruises in 2015 and 2018. The dotted red line for $\Omega$ values represents the isopleths of 1 ; below such value is considered $\mathrm{CaCO}_{3}$ undersaturation. The black dots represent sample locations. Gray box represents an area with non-collected data.

(Fig. 3k, 1). These values are within the reported range of ${ }^{13} \mathrm{C}$ fractionation due to photosynthetic carbon fixation ${ }^{25,26}$. However, within the AMZ core, and lower deep oxycline, we observed contrasting differences in $\delta \delta^{13} \mathrm{C}_{\mathrm{POC}}$ values between both years. During $2015, \delta^{13} \mathrm{C}_{\mathrm{POC}}$ values were as low as $-32 \%$ (Fig. $3 \mathrm{k}$ ), particularly at $300 \mathrm{~m}$ depth at Stn 2, and down to $400 \mathrm{~m}$ at Stn 6 . Notably, even more isotopically depleted $\delta^{13} \mathrm{C}_{\mathrm{POC}}$ values were detected in oxic deep waters below the AMZ and down to $1000 \mathrm{~m}$ (Stn 6; Fig. 3k). On the other side, during 2018, $\delta^{13} \mathrm{C}_{\mathrm{POC}}$ values within the AMZ core and deeper waters were more isotopically enriched and ranged from -23 to $-28 \%$ (Fig. 31).

The estimated values of $\delta^{13} \mathrm{C}_{\mathrm{CO} 2}$, as well as the respective isotopic fractionation $(\varepsilon)$ against ${ }^{13} \mathrm{C}$ between $\mathrm{CO}_{2}$ and $\mathrm{POC}$, and DIC and POC, show contrasting conditions both through the water column of each year and between both years, especially below the lower oxycline (down to $400 \mathrm{~m}$ depth; Supplementary Fig. 4). In 2015, from the lower deep oxycline down to $1000 \mathrm{~m}$ depth, $\boldsymbol{\varepsilon}$ values varied $\sim 21-23 \%$ and $\sim 32-33 \%$ for $\mathrm{CO}_{2}$-POC and DIC-POC, respectively (Supplementary Fig. 4c, e). In 2018, $\varepsilon$ values were $\sim 17 \%$ and $<24 \%$ for $\mathrm{CO}_{2}$-POC and DIC-POC over almost the entire water column, respectively (Supplementary Fig. 4d, f).

Calcium carbonate saturation state. We observed distinct conditions for calcium carbonate saturation state $(\Omega)$ between both expeditions. During 2015, waters below $100 \mathrm{~m}$ were corrosive for aragonite, as depicted by $\Omega_{\text {arag }}<1.0$ (Fig. 5a) and low $\mathrm{pH}$ values $<$ 7.8 (Fig. 2d). However, the calcite saturation horizon $\left(\Omega_{\text {calc }}<1.0\right)$ was not observed in the upper $1000 \mathrm{~m}$ of the water column during both years (Fig. 5c, d). In 2015, both $\Omega_{\text {arag }}$ and $\Omega_{\text {calc }}$ were low at the lower deep oxycline between 350 and $450 \mathrm{~m}$ depth (Fig. 5a, c). Contrarily, both aragonite and calcite-undersaturated conditions were not observed in the water column in 2018, with a shoaling towards the coast (at $100 \mathrm{~m}$ depth in Stn 1), while $\Omega_{\text {arag }}$ values $<$ 1.0 were observed in bottom waters (Fig. 5b). 
Model. We used a simple carbon isotope mass balance model to determine the potential sources of microbially produced organic matter within AMZ waters, and to estimate how much of this carbon is exported to deeper waters in this region. The results of our carbon isotope model demonstrate that the potential contribution of microbial production to carbon export varies greatly $(\sim 7-35 \%)$, which relies on a net fractionation factor $\left(\varepsilon_{\text {Famz }}\right)$ of carbon fixation via autotrophic production in the AMZ, and the relative proportion of carbon fixed as $\mathrm{HCO}_{3}$ vs $\mathrm{CO}_{2}$ (Fig. 6). By incorporating depth integrated carbon fixation rates of each prominent autotrophic metabolism in the AMZ (see Table 1), we applied a weighted average to estimate the net fractionation associated with AMZ autotrophy ( $\varepsilon_{\text {Famz }}$ : see Table 2$)$ under two contrasting scenarios. Since AMZ systems are temporally variable, the two scenarios reflect the different possible ranges of metabolic rates between distinct seasonal conditions in 2015 and 2018 (i.e. high SDAD vs low SDAD, respectively). The model results demonstrate a significant difference in the microbial contribution to organic carbon export below the AMZ between years, ranging from $\sim 2-17 \%$ greater in 2015 than 2018 (Fig. 6). This marked difference in the potential microbial contribution to POC below the AMZ (as much as double in 2015 than 2018) appears to be largely driven by the systematically heavier $\delta^{13} \mathrm{C}_{\mathrm{POC}}$ ( $\sim 5 \%$ across all depths) in 2018 , likely a result of an increased phytoplanktonic contribution to the organic carbon pool.

The remineralization rates in the euphotic zone and AMZ have a significant impact on the calculations of microbial contribution; as values approach complete recycling of AMZ-produced carbon (AMZ Remineralization $=100 \%$ ), the contribution of microbial production expectedly approaches $0 \%$ (see Eq. 3). Remineralization in the euphotic zone is kept at $95 \%$ in all conditions to reflect realistic degradation rates of surface-derived organic matter in

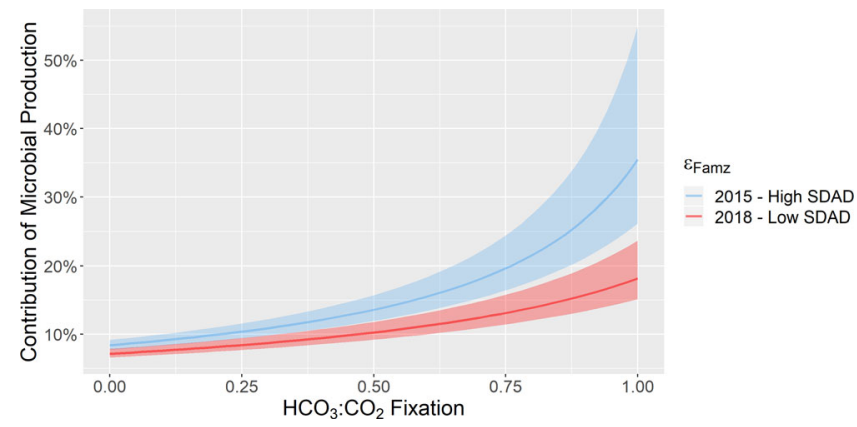

Fig. 6 Summary results of carbon isotope model under range of inorganic carbon conditions and Low/High SDAD Scenarios. $\varepsilon_{\mathrm{Famz}}$ indicates the net fractionation factor based on a weighted average of each autotrophic metabolism expected to be active in the AMZ. Shaded areas denote error estimates in $\varepsilon_{\text {Famz }}$ derived from the mean fractionation factors of individual autotrophic metabolisms. this region at $300 \mathrm{~m}^{27}$, meaning that $\sim 5 \%$ of what is produced in the surface is exported to the AMZ (see Table 2).

The fixation of $\mathrm{HCO}_{3}{ }^{-}$vs $\mathrm{CO}_{2}$ in the euphotic zone has no effect between model runs; the ${ }^{13} \delta \mathrm{C}_{\mathrm{POC}}$ in the surface remains the same as the $\varepsilon_{\mathrm{Fez}}$ is adjusted to remain consistent with the measured isotopic composition of the organic carbon pools. However, the model also demonstrates that the form of inorganic carbon utilized in the AMZ has a significant impact on the isotopic composition of POC in the $\mathrm{AMZ}$, and thus the estimated total microbial contribution (Fig. 6). By incorporating relative contributions determined from the total range of metabolic rates reported in the literature for each autotrophic process present in the ETSP AMZ, we estimate the microbial contribution to organic carbon export to range between $\sim 7$ and $18 \%$ in the 2018 cruise, and between $\sim 9$ to $35 \%$ in the 2015 cruise (Table 2 and Fig. 6).

\section{Discussion}

Geochemical and stable isotope data from two expeditions to the AMZ off northern Chile with contrasting oceanographic regimes highlight the biogeochemical variability of this environment. The interaction of local processes, such as the strength and spatial variation of upwelling conditions ${ }^{28}$, and its interconnection with regional processes, such as the intensity and displacement of mesoscale eddies $^{29}$, in addition to the advection of tropical waters, determine surface productivity and the variability of the zonal and vertical boundaries of the AMZ core. The latter can in turn influence carbon cycling and export in this region - i.e., the source and fate of different carbon pools through the water column. Previous studies in the area have shown the accumulation of nitrite $\left(>0.5 \mu \mathrm{mol} \mathrm{kg}^{-1}\right)^{13}$ in oxygen-free waters ${ }^{30}$ between 200 and $300 \mathrm{~m}$ depth along the coast (ca. $20-26^{\circ} \mathrm{S}$ ). Anoxia is maintained by both the remineralization of organic matter produced in surface waters and the low ventilation due to strong stratification $^{31,32}$

Anoxic waters were characterized by low $\mathrm{pH}$ and high $p \mathrm{CO}_{2}$ conditions $\left(\mathrm{pH}<7.5\right.$ and $\left.\mathrm{pCO}_{2}>1200 \mu \mathrm{atm}\right)$, which places the AMZ of the ETSP as one of the most oxygen-deficient and acidic systems worldwide ${ }^{32-35}$. Carbonate chemistry in the AMZ is also highly temporal and spatially variable, as reflected by the contrasting levels of DIC concentration and $\mathrm{pH}$ between austral spring 2015 and summer 2018. Our results evidence that the ETSP AMZ off the coast of northern Chile embodies one of the shallowest ( 100-400 m depth), low $\mathrm{pH}$, high $p \mathrm{CO}_{2} \mathrm{AMZ}$ systems in the world ${ }^{5}$, similar to what has been observed off the Peruvian coast ${ }^{29}$. Indeed, the aragonite saturation depth can be as shallow as $100 \mathrm{~m}$ depth, as observed during austral spring in 2015. The position of the AMZ core is also dynamic, with an AMZ core farther offshore during 2015 and more restricted to the continental shelf in 2018.

Notably, during 2015 we observed a decrease in DIC and aqueous $\mathrm{CO}_{2}\left(\mathrm{CO}_{2 \text {-aq }}\right)$ concentrations down to $\sim 30 \mu \mathrm{mol} \mathrm{kg}{ }^{-1}$ in the AMZ core relative to adjacent, similarly oxygen-depleted

\begin{tabular}{|c|c|c|c|c|}
\hline Carbon fixation & Low light cyanobacteria & SDAD Bacteria & Nitrifying archaea/bacteria & Anammox bacteria \\
\hline Max C-Fixation Rate & 0.87 & $8.4^{b}$ & 3.58 & 1.204 \\
\hline Mean C-Fixation Rate & 0.31 & 4.36 & 2.54 & 0.644 \\
\hline Fractionation Factor $(\varepsilon F)$ & $-17.3 \pm 1.2 \%$ & $-24.85 \pm 0.45 \%$ & $-19.3 \pm 0.3 \%$ & $-18.2 \pm 2.58 \% \circ$ \\
\hline
\end{tabular}

Isotope mass balance model includes average rates for each metabolism, except sulfur-driven autotrophic denitrification (SDAD)

aMinimum carbon fixation rate applied for SDAD bacteria under Low SDAD scenario

bMaximum carbon fixation rate applied for SDAD bacteria under High SDAD scenario 


\begin{tabular}{|c|c|c|}
\hline Model variable & High SDAD scenario & Low SDAD scenario \\
\hline${ }^{13} \mathrm{\delta C}_{\mathrm{OCamz}}$ & $-23 \% 0$ & $-17.5 \%$ \\
\hline${ }^{13} \mathrm{\delta C}_{\mathrm{OCamz}}$ & $-28.5 \%$ & $-23.5 \%$ \\
\hline$\varepsilon_{\mathrm{Fe}}$ & $-14.6 \%$ & $-8.6 \%$ \\
\hline$\varepsilon_{\mathrm{Rez}}$ & $1 \% o$ & $1 \% o$ \\
\hline$\epsilon_{\mathrm{Famz}}{ }^{\mathrm{a}}$ & $-23.1 \pm 0.55 \% \circ$ & $-19.4 \pm 0.77 \% \circ$ \\
\hline$\varepsilon_{\text {Ramz }}$ & $1 \% 0$ & $1 \% 0$ \\
\hline${ }^{13} \delta C_{\text {DICez }}$ & $-7.5 \%$ & $-8 \%$ \\
\hline${ }^{13} \delta C_{\text {DICamz }}$ & -5.5 to $-10.5 \%$ & -5.8 to $-11 \%$ \\
\hline $\mathrm{R}_{\mathrm{ez}}$ & 0.95 & 0.95 \\
\hline$R_{a m z}$ & 0.90 & 0.90 \\
\hline Year & 2015 & 2018 \\
\hline
\end{tabular}

$\mathrm{HCO}_{3}: \mathrm{CO}_{2}$ utilization is the ratio of $\mathrm{HCO}_{3}$ utilization to $\mathrm{CO}_{2}$ utilization in carbon fixation ez euphotic zone, $A M Z$ anoxic marine zone, $O C$ organic carbon, DIC dissolved inorganic carbon, $\varepsilon$ fractionation factor (F-carbon fixation, R-respiration), SDAD sulfur-driven autotrophic

denitrification, ${ }^{13} \delta \mathrm{C}$ isotopic composition of carbon pool

${ }^{\mathrm{a}} \mathcal{E}_{\mathrm{Famz}}$ is based on a weighted average of fractionation factors dependent on the relative carbon fixation rates of each autotrophic metabolism present in the AMZ

waters (Supplementary Fig. 2A). In the same study area, Paulmier et al. ${ }^{12}$ observed a similar carbon deficit associated with the OMZ, which they related to oxygen loss due to thermal mechanisms during $\mathrm{OMZ}$ water formation in the equatorial region, since a decrease in DIC is expected in warm regions due to a lowering of gas solubility. Indeed, when we analyze $\mathrm{pCO}_{2}$ data collected in the ETSP between 7 and $15^{\circ} \mathrm{S}^{29}$ shows a steady reduction in $p \mathrm{CO}_{2}$ as the Equatorial Subsurface Waters (ESSW) move southward along the Peruvian coast. Here, we explore the hypothesis that microbial processes involved in sulfur and nitrogen cycling can exert an additional partial control for such DIC deficit. For instance, the generally increased DIC concentrations in high- $\mathrm{N}^{*}$ and low- $\mathrm{O}_{2}$ waters suggests active organic matter respiration via nitrate reducers, with the canonical denitrification pathway responsible for part of the $\mathrm{N}^{*}$ registered in both years $(>-20 \mu \mathrm{mol} \mathrm{kg}-1)$, which was remarkably high during 2018 (up to $-40 \mu \mathrm{mol} \mathrm{kg}^{-1}$ ). Thus, while organic matter remineralization is expected to reduce alkalinity due to proton production, the observed high $\mathrm{A}_{\mathrm{T}}$ in both years could be explained by a net nitrate input from an external source feeding nitrate reducers and denitrifiers ${ }^{36}$, as expected to occur particularly during the upwelling-active period registered in 2018. Inversely, the low DIC concentrations in the $\mathrm{O}_{2}$-depleted and $\mathrm{N}$-deficient waters observed in some stations (Stns 5-6) during 2015 could be associated with dark carbon fixation.

The $\delta^{13} \mathrm{C}_{\mathrm{DIC}}$ and $\delta^{13} \mathrm{C}_{\mathrm{POC}}$ data suggest that chemosynthetic processes, which could reduce $p \mathrm{CO}_{2}$ in the $\mathrm{AMZ}^{36,37}$, were likely more dominant during 2015. It is well known that AMZs host an active and diverse autotrophic and heterotrophic microbial community ${ }^{10,13}$. Indeed, the unusually depleted $\delta^{13} \mathrm{C}_{\mathrm{POC}}$ values, along with the $\varepsilon$ values for $\mathrm{CO}_{2} / \mathrm{DIC}$ and POC observed in the AMZ core in 2015, reinforce the idea that inorganic carbon fixation processes such as SDAD and anammox ${ }^{20}$, previously reported to be active in oxygen-deficient regions ${ }^{38,39}$, might significantly influence the carbonate chemistry of AMZs. However, the low carbon fixation rates estimated through anammox ${ }^{15}$ ( $\sim 0.0004 \mu \mathrm{mol} \mathrm{C} \mathrm{L}{ }^{-1} \mathrm{~d}^{-1}$; based on a C:N $\left.=0.066 / 1\right)$ compared

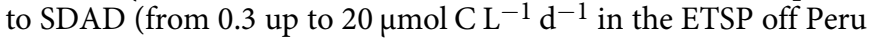
and Chile; Supplementary Table 1), support the idea that SDAD, with a higher carbon isotopic fractionation factor (mean of $-24.8 \%{ }^{40}$ ) than anammox (mean of $-18.2 \%{ }^{20}$ ), could be the dominant chemolithoautotrophic process driving carbon fixation in the AMZ. Although some studies suggest that SDAD can only be important in coastal $\mathrm{AMZ}$ waters ${ }^{41}$, sulfide oxidation rates calculated for the same study area (i.e. although with sulfide concentrations higher than in situ conditions) were high (i.e. relative to anammox and denitrification rates), and strongly coupled to nitrate reduction ${ }^{13}$. High sulfide oxidation activity has also been linked to metagenome analysis in our study area, which indicates the occurrence of enriched sequences matching the genomes of sulfur-oxidizing endosymbionts lineages (i.e. like Candidatus Ruthia magnifica, Candidatus Vesicomyosocius okutanii, and SUP05 pelagic linage), especially during spring/summer conditions ${ }^{10,13,16}$, such as in our 2015 expedition (i.e. austral spring). It has been suggested that sulfide oxidation is mainly sustained by sulfate reduction; however, the undetectable sulfide accumulation in OMZ/AMZ waters seems to be associated with its immediate oxidation back to sulfate, or to different sulfur intermediate compounds ${ }^{42}$, as part of what has been described as a cryptic sulfur cycle ${ }^{13}$. Furthermore, offshore SDAD activity could also be supported by eddy-driven zonal advection (i.e. a mesoscale process particularly active for northern Chile ${ }^{43}$ ) of SUP05 species and hydrogen sulfide that is frequently accumulated in OMZ shelf waters ${ }^{39,44}$. Actually, mesoscale eddies in this region can persist for weeks or months ${ }^{45}$. Moreover, Stn T5 is only $\sim 75-80 \mathrm{~km}$ offshore. Therefore, a conservative estimate of sulfide oxidation using the ranges reported by both Canfield et al. ${ }^{13}$ and Callbeck et al. ${ }^{39}$ off northern Chile and Peru, respectively, as well as mean anammox rates for the same area ${ }^{46-50}$, suggests that dark carbon fixation could remove from 0.12 up to $0.63 \mu \mathrm{mol} \mathrm{C} \mathrm{L}{ }^{-1}$ day $^{-1}$ during the southward travel of the ESSW. A study in the ETNP OMZ off Mexico ${ }^{51}$ also reported high DIC assimilation at the OMZ core $\left(6.4 \mu \mathrm{mol} \mathrm{C} \mathrm{L}^{-1} \mathrm{~d}^{-1}\right)$ in association with depleted $\delta^{13} \mathrm{C}_{\mathrm{POC}}$ values ( $-30.3 \%$ ), which they assigned to anammox activity based on molecular biomarkers analyses. However, Cavan et al. $^{52}$ already suggested that anammox is unlikely to be solely responsible for dark carbon fixation in OMZ waters offshore. As stated above, the low anammox rates reported for our study area suggest that this metabolism plays a rather neglectable role in the DIC deficit in the core AMZ, despite the fact that enough $\mathrm{NH}_{4}{ }^{+}$, the apparent limiting substrate, is produced in the ETSP off northern Chile (Supplementary Table 2). Our results provide a robust biologically mediated mechanism for the observed DIC variability found in AMZs (deficit or accumulation), although we cannot rule out additional processes (biological/physical).

Aerobic $\mathrm{NH}_{4}{ }^{+}$oxidizers, considered to be the main chemoautotrophs in the ocean ${ }^{53}$, have an $\varepsilon$ similar to anammox (mean of $19.3 \%{ }^{54}$ ), and they can support up to $50 \%$ of the total dark carbon fixation in the upper oxycline of the ETSP AMZ ${ }^{55}$. However, the contribution of this process to carbon cycling within the AMZ is likely neglectable, as its activity ${ }^{5-57}$ and the abundance and expression of genes that regulate this pathway ${ }^{10,16,56}$ decrease with depth in the AMZ. For instance, $\mathrm{NH}_{4}{ }^{+}$oxidation rates drop three orders of magnitude in experiments using water from the oceanic AMZ oxycline $\left(250 \mu \mathrm{mol} \mathrm{O} \mathrm{L}^{-1} ; 800 \mathrm{nmol} \mathrm{N} \mathrm{L}^{-1} \mathrm{~d}^{-1}\right)^{55}$, the upper AMZ $\left(<5 \mu \mathrm{mol} \mathrm{O} \mathrm{L}^{-1} ; 150 \mathrm{nmol} \mathrm{N} \mathrm{L}^{-1} \mathrm{~d}^{-1}\right)$, and the AMZ core $\left(6 \mathrm{nmol} \mathrm{O}_{2} \mathrm{~L}^{-1} ; 4 \mathrm{nmol} \mathrm{N} \mathrm{L}{ }^{-1} \mathrm{~d}^{-1}\right)^{57}$. At depressed rates, $\mathrm{NH}_{4}+$ oxidizers fix $0.5 \mathrm{nmol} \mathrm{C} \mathrm{L}-1 \mathrm{~d}^{-1}$ (based on a C:N ratio $=$ $1.0: 8.3)^{58}$, which is three orders of magnitude lower than the mean C fixation estimated for SDAD in the AMZ (see Supplementary Table 2). Nevertheless, since part of the particulate material settled to the AMZ could have the $\delta^{13} \mathrm{C}$ imprint from $\mathrm{NH}_{4}{ }^{+}$oxidizers at the oxycline and/or at the upper OMZ boundary, its potential contribution to the organic carbon pool in the AMZ should be considered.

Increased $\mathrm{A}_{\mathrm{T}}\left(>2300 \mu \mathrm{mol} \mathrm{kg}{ }^{-1}\right)$ and high DIC concentrations $\left(>2200 \mu \mathrm{mol} \mathrm{kg}^{-1}\right.$ in some samples) in $\mathrm{O}_{2}$-depleted and $\mathrm{N}$ deficient waters suggest a predominance of heterotrophic denitrification over autotrophic processes during 2018. Furthermore, 
the $\varepsilon$ values between $\mathrm{CO}_{2}$ and POC, as well as between DIC and POC, were significantly lower than in 2015 over almost the entire water column ( $17 \%$ and $24 \%$, respectively). Therefore, and considering the higher phytoplankton and POC biomass in surface waters during 2018, our results suggest that most (or at least a significant fraction) of the organic carbon exported to the AMZ and below derives from recently settled photosynthetically-fixed carbon in surface waters ${ }^{25,26,59}$. This fresh organic material might have stimulated the heterotrophic community, particularly the fast-growing denitrifiers ${ }^{49,60}$ (i.e. relative to the slow growing anammox bacteria ${ }^{61}$ ). This argument is also confirmed from previous studies in the same region ${ }^{49,60}$, where the highest denitrification rates were found associated with areas with high chlorophyll levels in the euphotic zone. In general, $\mathrm{N}$ cycling in the AMZ is tightly coupled to the organic matter produced and exported from the surface ${ }^{60}$.

The dominant microbial functional types found in the AMZ core of this region have the potential for sulfur/ammonium oxidation, nitrate/nitrite reduction, and especially inorganic carbon fixation $(\mathrm{C} 1 \text { carbon fixation })^{10}$, with denitrification, anammox, and sulfur oxidation pathways as the dominant processes in the core of the AMZ ${ }^{10,13}$. SUP05 and SAR324 are well-known bacterial clades with the metabolic flexibility to perform bicarbonate (DIC) uptake ${ }^{13,62}$ as well as methane oxidation ${ }^{63}$, and they are common in this oxygen-limited system ${ }^{10} .{ }^{15} \mathrm{~N}$-tracer approaches have confirmed active N-loss through denitrification and anammox in this region ${ }^{48,50,64}$, although both processes exhibit high spatiotemporal variability in this and other AMZ systems ${ }^{65-67}$. In general, anammox, which is particularly predominant in the ETSP, is highly active just below the upper AMZ boundary, and declines exponentially with depth ${ }^{48,49}$. However, no depth dependence has been discerned for denitrification ${ }^{49}$. On the other hand, beyond oxygen limitation ${ }^{47,68,69}$, the input of electron donors exerts a main control of $\mathrm{N}$-removal processes, i.e., organic matter quality and lability $60,70, \mathrm{NH}_{4}{ }^{+}$availability from organic matter remineralization $46,48,56,60$, and sulfide readiness ${ }^{13,38}$. Thus, the observed variability in the dominance of different microbial processes between 2015 and 2018 is likely associated with the seasonal oceanographic dynamic reported for AMZ waters in this region $^{28,71}$. Our 2015 sampling occurred during austral spring conditions and under a moderated upwelling regime with a narrow upwelling signal at the coast, whilst the 2018 sampling occurred during an intense summer upwelling event with high

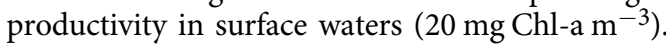

The export of organic matter from dark carbon fixation processes occurring in AMZ waters to deeper layers of the ocean may contribute to the depleted $\delta^{13} C_{\mathrm{POC}}$ signatures found in waters below the AMZ in 2015. A recent organic geochemical study in the AMZ off northern Chile ${ }^{72}$ reported that a biomarker specific of anammox bacteria ${ }^{73}$ was not only abundant in the suspended organic matter within AMZ waters, but also in oxygenated waters below, possibly indicating the occurrence of exported biomass from the AMZ, and/or active anammox bacteria in anoxic microniches within sinking particles. However, the lack of robust biomarkers for SDAD makes a quantitative comparison of the relative contribution of anammox vs. SDAD to POC using biomarkers in AMZ regions still difficult.

Our carbon isotope-mixing model investigated the potential contribution of microbial autotrophs in AMZ waters based on the net isotopic fractionation factor $\left(\varepsilon_{\mathrm{Famz}}\right)$ during carbon fixation. The model includes contributions from low light-adapted cyanobacteria, anammox bacteria, nitrifying archaea/bacteria, and sulfide-oxidizing bacteria during the two cruises. The carbon chemistry and C:N stoichiometries from the 2015 and 2018 cruises suggest a dynamic shift, in terms of carbon fixation, from a SDAD dominated AMZ to a largely photoautotrophic/nitrifying system. Thus, we applied the carbon isotope model under two distinct scenarios, a relatively high SDAD scenario to reflect the conditions in the 2015 cruise, and a low SDAD scenario in 2018 (Table 2). In order to constrain the potential range of total microbial contribution to carbon export, we compared depthintegrated metabolic rates of chemoautotrophy in the AMZ under these two generalized scenarios (Table 1). The model results indicate that the total microbial contribution from AMZ waters to carbon export likely ranged between $\sim 7$ and $18 \%$ in the 2018 cruise, and between $\sim 9$ and $35 \%$ in the 2015 cruise (Fig. 6). Our estimates provide quantitative evidence for a significant and novel secondary source of organic carbon exported to the mesopelagic region from oxygen-deficient waters that have been generally overlooked. Recently, using intact polar lipids in size-fractionated POM, Cantarero et al. ${ }^{74}$ suggested that the standing stock of microbial biomass in AMZ waters of this system might be larger than that of the oxic photic zone, thus supporting the notion that dark carbon fixation might contribute to carbon export to the deeper ocean. Indeed, Lengger et al. ${ }^{75}$ demonstrated that organic carbon produced through chemoautotrophic carbon fixation could constitute a substantial proportion (17\%) of the organic matter exported from the Arabian Sea OMZ to underlying surface sediments.

It has been suggested that similar to episodes of transient warming in earth history, modern and future ocean warming could impact the oceanic biological pump, largely via increasing surface ocean temperature ${ }^{76}$, a reduction in the remineralization $\operatorname{depth}^{77,78}$, and therefore reduced $\mathrm{CO}_{2}$ storage $^{76}$. Our results highlight the potential implications of enhanced microbial processes in AMZ waters 77 as a source of isotopically depleted organic carbon that has not been considered when estimating changes in carbonate chemistry and carbon cycling in projections of AMZ expansion. Moreover, dark carbon fixation by microorganisms involved in nitrogen, carbon, and sulfur cycling could also influence, through dark carbon fixation, the carbonate chemistry conditions $\left(\mathrm{pH}, \mathrm{A}_{\mathrm{T}}\right.$, and $p \mathrm{CO}_{2}$ ) for temporary or permanent AMZ inhabitants ${ }^{79}$. Thus, the recent evidence for decreasing $\mathrm{pH}$ due to reduced ventilation in the deep ocean ${ }^{80}$ deserves revision in some oceanic regions, since such conclusions do not consider the role of microbially mediated biogeochemical processes associated with sulfur and nitrogen cycles, which can modify the carbonate chemistry in AMZ waters at depth. In consequence, there is a need for new biogeochemical models that take into account sulfur/nitrogen-driven microbial processes occurring in AMZs under future scenarios of ocean change.

\section{Methods}

Field sampling and hydrographic profiles. Samples were collected during two expeditions to the ETSP off northern Chile during late November 2015 (LowpHOX 1) and February 2018 (LowpHOX 2) onboard the R/V Cabo de Hornos. The sampling design during 2015 considered an inshore-offshore transect off Iquique $\left(20^{\circ} \mathrm{S}\right)$ with six sampling stations (T1-T6), and a longitudinal transect with six sampling stations (L1-L6) from $20^{\circ}$ down to $29.5^{\circ} \mathrm{S}$ (Fig. 1). During 2018 we studied three sampling stations along the inshore-offshore transect (T1, T3, and T5).

Hydrographic profiles were recorded during both cruises using the same SeaBird SBE-911+ CTD system equipped with two temperature and conductivity sensors, a SBE 43 oxygen sensor and fluorometer, and 24 10-L General Oceanic Niskin Bottles. Temperature and conductivity sensors were pre-cruise calibrated. The raw data were processed following the recommended procedures provided by the manufacturer and were averaged into one dbar bins. Additionally, a pump profiling system (PPS) was also used for water collection and high-resolution $\mathrm{O}_{2}$ measurement.

Upwelling index and MODIS images. The Upwelling Index is based on Ekman Transport estimates provided by NOAA ERDDAP (http://coastwatch.pfeg.noaa gov/erddap/griddap/erdlasFnTran6.html). The horizontal resolution of the transport estimates is $1 \times 1^{\circ}$ latitude $\times$ longitude on a 6 -h interval. We chose the grid point at $20.5^{\circ} \mathrm{S}$ and $70.5^{\circ} \mathrm{W}$ offshore Iquique. The Upwelling Indices were calculated with an algorithm published by NOAA ERDDAP on their website. 
The data to compute Sea Surface Temperature and Chlorophyll-a maps were obtained from the MODIS-Aqua website https://oceandata.sci.gsfc.nasa.gov/ MODIS-Aqua/Mapped/8-Day/4km/. MODIS (or Moderate Resolution Imaging Spectroradiometer) is a key instrument aboard the Terra (originally known as EOS AM-1) and Aqua (originally known as EOS PM-1) satellites. Terra's orbit around the Earth is timed so that it passes from north to south across the equator in the morning, while Aqua passes south to north over the equator in the afternoon. Terra MODIS and Aqua MODIS screen the Earth's surface every 1-2 days, acquiring data in 36 spectral bands, or groups of wavelengths (see MODIS Technical Specifications). The horizontal resolution of the database is $4 \times 4 \mathrm{~km}$ and 8-day composites of cloud-free ocean are provided.

Chlorophyll a, dissolved nutrients, and elemental stoichiometry. Chlorophyll $a$ concentration and dissolved inorganic $\mathrm{N}$ (nitrite, $\mathrm{NO}_{2}{ }^{-}$and nitrate, $\mathrm{NO}_{3}{ }^{-}$) and phosphate $\left(\mathrm{PO}_{4}{ }^{3-}\right)$ were analyzed using standard protocols ${ }^{81,82}$. In order to calculate the deviation from the classical Redfield ratio $(\mathrm{N}: \mathrm{P}=16: 1)$ (Redfield et al. 1963), we calculated the tracer $\mathrm{N}^{*} 83$ (Eq. 1):

$$
\mathrm{N}^{*}=\left(\left[\mathrm{NO}_{3}^{-}\right]-16 \times\left[\mathrm{PO}_{4}^{3-}\right]+2.9\right) \times 0.87
$$

where $\left[\mathrm{NO}_{3}{ }^{-}\right]$and $\left[\mathrm{PO}_{4}{ }^{3-}\right]$ are the concentrations of nitrate and phosphate in $\mu \mathrm{mol} \mathrm{kg}{ }^{-1}$, respectively. Positive and negative $\mathrm{N}^{*}$ are an indicator of an excess or deficit of $\mathrm{NO}_{3}{ }^{-}$relative to $\mathrm{PO}_{4}{ }^{3-}{ }^{-82}$, respectively, and values are typically arbitrary units rather than absolute concentrations.

Carbon pools and stable isotope analyses. Samples for $\mathrm{pH}_{\mathrm{T}}$ were collected in $50 \mathrm{~mL}$ syringes and immediately transferred to a $25 \mathrm{~mL}$ thermostatted cell at $25.0 \pm$ $0.1^{\circ} \mathrm{C}$ for standardization, with a pH meter Metrohm ${ }^{\circledast}$ using a glass combined double junction $\mathrm{Ag} / \mathrm{AgCl}$ electrode (Metrohm model 6.0258.600), which was calibrated with 8.089 Tris buffer solution as a certified reference material (CRM, supplied by Andrew Dickson, Scripps Institution of Oceanography, San Diego, USA) at $25^{\circ} \mathrm{C}$. $\mathrm{pH}$ values are reported on the total scale $\left(\mathrm{pH}_{\mathrm{T}}\right)$. Samples for total alkalinity $\left(\mathrm{A}_{\mathrm{T}}\right)$ were poisoned with $50 \mu \mathrm{L}$ of saturated $\mathrm{HgCl}_{2}$ solution and stored in $500 \mathrm{~mL}$ borosilicate BOD bottles with ground-glass stoppers lightly coated with Apiezon $\mathrm{L}^{\circ}$ grease and kept in darkness and room temperature. $\mathrm{A}_{\mathrm{T}}$ was determined using the open-cell titration method ${ }^{84}$, by using an automated Alkalinity Tritrator Model AS-ALK2 Apollo SciTech. All samples were analyzed at $25^{\circ} \mathrm{C}\left( \pm 0.1{ }^{\circ} \mathrm{C}\right)$ with temperature regulation using a water-bath. Analytical accuracy was controlled against a certified reference material (CRM, supplied by Andrew Dickson, Scripps Institution of Oceanography, San Diego, USA) and the $\mathrm{A}_{\mathrm{T}}$ repeatability averaged $2-3 \mu \mathrm{mol} \mathrm{kg}{ }^{-1}$. DIC samples were collected in $250 \mathrm{~mL}$ Wheaton ${ }^{\circledR}$ glass bottles and preserved with $50 \mu \mathrm{L}$ saturated $\mathrm{HgCl}_{2}$ solution. Immediately after opening the sample bottle, a digital syringe withdrew a small volume $(0.5 \mathrm{ml})$, acidified it with $10 \%$ phosphoric acid and subsequently measured the evolved $\mathrm{CO}_{2}$ with a LICOR 6262 non-dispersive infrared gas analyzer. Certified seawater reference materials from A. Dickson were used to ensure the quality of DIC determination by preparing a calibration curve covering the range of DIC from $200-2000 \mu \mathrm{eq} \mathrm{L}^{-1}$, with a resulting precision averaging $\approx 0.1 \%$ (range $0.05-0.5 \%$ ). Temperature, salinity, $\mathrm{A}_{\mathrm{T}}$, and DIC data were used to calculate aqueous $\mathrm{CO}_{2}\left(\mathrm{CO}_{2}\right.$-aq), $p \mathrm{CO}_{2}$, and Calcite Saturation State $\left(\Omega_{\text {calcite }}\right)$ Analyses were performed using $\mathrm{CO}_{2} \mathrm{SYS}$ software for MS Excel $^{85}$ set with Mehrbach solubility constants ${ }^{86}$ refitted by Dickson \& Miller ${ }^{87}$. The $\mathrm{KHSO}_{4}$ equilibrium constant determined by Dickson ${ }^{88}$ was used for all calculations.

Stable isotopic $\left(\delta^{13} \mathrm{C}\right)$ measurement of DIC was performed following a method modified version of the method by Torres et al $(2015)^{89}$. Seawater DIC samples were collected in $250 \mathrm{~mL}$ Wheaton ${ }^{\circledast}$ glass bottles and preserved with $50 \mu \mathrm{L}$ saturated $\mathrm{HgCl}_{2}$ solution. Inside a glove bag, $1 \mathrm{~mL}$ water sample was transferred into pre-cleaned $\left(10 \% \mathrm{HCl}\right.$-rinsed and $540^{\circ} \mathrm{C} / 4 \mathrm{hrs}$ combusted) $12 \mathrm{~mL}$ Exetainer vials and then capped before sealing the vial with an ultra-high purity helium headspace. DIC samples were acidified with $50 \mu \mathrm{L} 85 \% \mathrm{H}_{3} \mathrm{PO}_{4}$ via syringe injection through the septum, and allowed to equilibrate at room temperature for 12 hours. Evolved headspace $p \mathrm{CO}_{2} \delta^{13} \mathrm{C}_{\text {DIC }}$ was then measured using a Gas Bench II and a Finnigan Delta Plus isotope ratio mass spectrometer at UC Irvine, with an analytical uncertainty of $\pm 0.05 \%$.

In order to estimate the isotopic signature of $\mathrm{CO}_{2}$ incorporated during uptake, we also estimated the $\delta^{13} \mathrm{C}$ of ambient $\mathrm{CO}_{2}$ (aq) by using the Eq. 2 derived from Rau et al. ${ }^{90}$

$$
\delta^{13} \mathrm{C}_{\mathrm{CO} 2}=\delta^{13} \mathrm{C}_{\mathrm{DIC}}+23.644-\left(9701.5 / T_{\mathrm{K}}\right)
$$

where $\delta{ }^{13} \mathrm{C}_{\mathrm{DIC}}$ is the $\delta{ }^{13} \mathrm{C}$ of ambient DIC and $T_{\mathrm{K}}$ is the corresponding temperature in Kelvin scale.

Seawater samples $(500-1000 \mathrm{~mL})$ were collected by vacuum filtration through pre-combusted $\left(4 \mathrm{~h}\right.$ at $\left.450^{\circ} \mathrm{C}\right) \mathrm{MFS} \mathrm{GF} / \mathrm{F}$ glass fiber filters $(0.7 \mu \mathrm{m}$ nominal pore size, $25 \mathrm{~mm}$ diameter) for POC analyses. Prior to filtration, filters were rinsed with $10 \% \mathrm{HCl}$ followed by deionized water to eliminate any trace of inorganic carbon. In 2015 cruise, POC concentration and $\delta^{13} C_{\mathrm{POC}}$ were determined at the Stable Isotope Facility at the University of California Davis by using an Elementar Vario EL Cuve or Micro Cube elemental analyzer (Elementar Analysensysteme GmbH, Hanau, Germany) interfaced to a PDZ Europa 20-20 isotope ratio mass spectrometer (Sercon Ltd., Cheshire, UK). The long-term precision reported is $\pm 0.2 \%$ for $\delta$ ${ }^{13} \mathrm{C}_{\mathrm{POC}}$ in this range with precision decreasing on the lower end. POC concentration and the $\delta^{13} \mathrm{C}_{\mathrm{POC}}$ for the 2018 cruise filtrates were measured using a Thermo Scientific Elemental Analyzer-Isotope Ratio Mass Spectrometer at the CU Boulder Earth Systems Stable Isotope Lab. Purified acetanilide, ethylenediaminetetraacetic acid, and in-house (Pugel) standards were measured for external calibration and drift corrections with a total carbon and nitrogen analytical precision between $1.1-2.2 \%$ and $0.6-2.2 \%$, respectively, and a $\delta^{13} C_{\mathrm{POC}}$ analytical precision between 0.09 and $0.17 \%$ across all analysis runs. During analysis, samples are interspersed with several replicates of at least two different laboratory standards.

Model. We utilized a carbon isotope mass balance model to determine potential sources of organic matter and estimate the impact of microbial dark autotrophic production to carbon export from the AMZ (Eqs. 3, 4 and 5); where ez is the euphotic zone, amz the anoxic marine zone, $\Phi$ represent the mass fluxes $(\mathrm{P}-$ primary productivity, R-respiration), $r_{e}$ is the remineralization in the euphotic zone, $r_{o}$ the remineralization in OMZ), $\delta$ is the isotopic composition of carbon pool, $\varepsilon$ is the fractionation factor (F-carbon fixation, R-respiration), OC is the organic carbon, and DIC the dissolved inorganic carbon concentration. The exported carbon pool in the mesopelagic region is described as a ratio of fluxes between net-AMZ and -total net primary production (i.e. euphotic zone + AMZ net primary production; Eq. 3). Remineralization rates are defined as the relative fluxes of respiration/production (Eq. 4). The contribution of productivity in the AMZ to carbon export $\left(f_{\text {onet }}\right)$ is defined in terms of: the net productivity fluxes, the isotopic fractionation factors $(\varepsilon)$ of carbon fixation and respiration in the euphotic zone and AMZ, and the isotopic composition of the organic and inorganic carbon pools in both the euphotic zone and AMZ (Eq. 5).

The measured $\delta^{13} \mathrm{C}$ of bulk organic matter and total dissolved inorganic carbon from both the euphotic and AMZs along the $2015+2018$ oceanographic expeditions are fed into Eq. 3 under a range of inorganic carbon conditions and 2 different scenarios of metabolic activity. We calculated $f_{\text {onet }}$ assuming different proportions of $\mathrm{HCO}_{3}$ and $\mathrm{CO}_{2}$ utilized in carbon fixation from AMZ autotrophy expressed as a ratio $\left(\mathrm{HCO}_{3}: \mathrm{CO}_{2}\right.$ fixation) from 0 to 1 . In addition, we calculated $f_{\text {onet }}$ under two scenarios (High SDAD and Low SDAD) by estimating an $\varepsilon_{\text {Famz }}$ value derived from a weighted average from depth integrated rates of carbon fixation from each autotrophic metabolism active in the AMZ (see Table 1 for summary of model conditions and scenarios).

$$
\begin{gathered}
f_{\mathrm{onet}}=\frac{\Phi_{\mathrm{amzP}} \Phi_{\mathrm{amzR}}}{\Phi_{\mathrm{amz} \mathrm{P}}-\Phi_{\mathrm{amzR}}+\Phi_{\mathrm{ezP}}-\Phi_{\mathrm{ezR}}} \\
r_{e}=\frac{\varepsilon_{\mathrm{Rez}}}{\varepsilon_{\mathrm{Fez}}} ; r_{o}=\frac{\varepsilon_{\mathrm{Ramz}}}{\varepsilon_{\mathrm{Famz}}} \\
f_{\mathrm{onet}}=\frac{\left(r_{o}-1\right)\left(\delta_{\mathrm{OCez}}-\delta_{\mathrm{OCamz}}\right)}{\left(r_{o}-1\right) \delta_{\mathrm{DICez}}+\delta_{\mathrm{DICamz}}-\epsilon_{\mathrm{Fez}}+r_{e} \epsilon_{\mathrm{Rez}}+\epsilon_{\mathrm{Famz}}-r_{o}\left(\delta_{\mathrm{OCamz}}-\epsilon_{\mathrm{Fez}}+r_{e} \epsilon_{\mathrm{Rez}}+\epsilon_{\mathrm{Ramz}}\right)}
\end{gathered}
$$

The autotrophic metabolisms present with significant carbon fixation rates within the AMZ in these model runs are limited to low light-adapted cyanobacteria, nitrifying bacteria/archaea, anammox bacteria, and sulfur-oxidizing bacteria. Average fractionation factors for each autotroph's respective carbon fixation pathway $20,40,54,91,92$ are incorporated into the model (Table 1) and expressed as a weighted average $\left(\varepsilon_{\mathrm{Famz}}\right.$; Table 2$)$ based on the relative rates of carbon fixation associated with each respective metabolism.

We included averaged depth-integrated carbon fixation rates of anammox ${ }^{46-50}$; aerobic $\mathrm{NH}_{4}{ }^{+}$oxidation ${ }^{55}$ and low-light-adapted cyanobacteria ${ }^{93}$, and $\mathrm{min} / \mathrm{max}$ rates of sulfide oxidation ${ }^{39}$ (i.e. corresponding to low/high SDAD scenarios, respectively). Depth integrated $\mathrm{NH}_{4}{ }^{+}$oxidation rates were estimated from discrete carbon fixation rates off northern Chile by Molina \& Farías ${ }^{55}$, assuming nitrifying bacteria/archaea to be limited to $\sim 100 \mathrm{~m}$ of the lower oxycline and upper OMZ. Sulfate-reducing bacteria in the ETSP are thought to be predominantly heterotrophic and provide a significant source of mineralized $\mathrm{NH}_{4}{ }^{+}$for anammox bacteria $^{13}$, but are not expected to be a significant source of fixed carbon and are thereby not included in this calculation.

\section{Data availability}

The data that support the findings of this study are available from the corresponding author upon reasonable request

Received: 16 July 2018; Accepted: 12 February 2021; Published online: 11 March 2021

\section{References}

1. Gilly, W. F. et al. Oceanographic and biological effects of shoaling of the oxygen minimum zone. Annu. Rev. Mar. Sci. 5, 393-420 (2013).

2. Long, M. C., Deutsch, C. \& Ito, T. Finding forced trends in oceanic oxygen. Global Biogeochem. Cycles 30, https://doi.org/10.1002/2015GB005310 (2016)

3. Wyrtki, K. The oxygen minima in relation to ocean circulation. Deep-Sea Res. 9, 11-23 (1962). 
4. Stramma, L. et al. Eastern Pacific oxygen minimum zones: Supply paths and multidecadal changes. J. Geophys. Res. 115, C9 (2010).

5. Paulmier, A. \& Ruiz-Pino, D. Oxygen minimum zones (OMZs) in the modern ocean. Progr. Oceanogr. 80, 113-128 (2009).

6. Whitney, F. A., Freeland, H. J. \& Robert, M. Persistently declining oxygen levels in the interior waters of the eastern subarctic Pacific. Progr. Oceanogr. 75, 179-199 (2007).

7. Stramma, L. et al. Expanding oxygen-minimum zones in the tropical oceans. Science 320, 655-658 (2008).

8. Emerson, S. et al. Temporal trends in apparent oxygen utilization in the upper pycnocline of the North Pacific: 1980-2000. J. Oceanogr. 60, 139-147 (2004).

9. Revsbech, N. P. et al. Determination of ultra-low oxygen concentrations in oxygen minimum zones by the STOX sensor. Limnol. Oceanogr. Methods 7 , 371-381 (2009).

10. Ulloa, O. et al. Microbial oceanography of anoxic oxygen minimum zones. Proc. Natl Acad. Sci. U. S. A. 109, 15996-16003 (2012).

11. Padilla, C. C. et al. Metagenomic binning recovers a transcriptionally active gammaproteobacterium linking methanotrophy to partial denitrification in an anoxic oxygen minimum zone. Front. Mar. Sci. 4, 23 (2017).

12. Paulmier, A., Ruiz-Pino, D. \& Garçon, V. $\mathrm{CO}_{2}$ maximum in the oxygen minimum zone (OMZ). Biogeosciences 8, 239-252 (2011).

13. Canfield, D. E. et al. A cryptic sulfur cycle in oxygen-minimum-zone waters off the Chilean coast. Science 330, 1375-1378 (2010).

14. Naqvi, S. W. A. et al. Budgetary and biogeochemical implications of $\mathrm{N}_{2} \mathrm{O}$ isotope signatures in the Arabian Sea. Nature 394, 462-464 (1998).

15. Koeve, W. \& Kähler, P. Heterotrophic denitrification vs. Autotrophic anammox-quantifying collateral effects on the oceanic carbon cycle. Biogeosciences 7, 2327-2337 (2010).

16. Stewart, F. J., Ulloa, O. \& DeLong, E. F. Microbial metatranscriptomics in a permanent marine oxygen minimum zone. Environ. Microbiol. 14, 23-40 (2012).

17. Ulloa, O. et al. in The Prokaryotes-Prokaryotic Communities and Ecophysiology (eds Rosenberg, E. et al.) (Springer-Verlag) https://doi.org/ 10.1007/978-3-642-30123-0_45 (2013).

18. Keil, R. G. et al. A multiproxy approach to understanding the "enhanced" flux of organic matter through the oxygen-deficient waters of the Arabian Sea. Biogeosciences 13, 2077-2092 (2016).

19. Santos, G. M. et al. $\delta^{14} \mathrm{C}$ and $\delta^{13} \mathrm{C}$ of seawater DIC as tracers of coastal upwelling: a 5-year time series from Southern California. Radiocarbon 53, 669-677 (2011).

20. Schouten, S. et al. Stable carbon isotopic fractionations associated with inorganic carbon fixation by anaerobic ammonium-oxidizing bacteria. Appl. Environ. Microbiol. 70, 3785-3788 (2004).

21. Feely, R. A. et al. The combined effects of ocean acidification, mixing, and respiration on $\mathrm{pH}$ and carbonate saturation in an urbanized estuary. Est. Coast. Shelf. Sci. 88, 442-449 (2010).

22. Brewer, P. \& Peltzer, E. T. Limits to Marine Life. Science 324, 347-348 (2009).

23. Franco, A. C. et al. Contrasting impact of future $\mathrm{CO}_{2}$ emission scenarios on the extent of $\mathrm{CaCO}_{3}$ mineral undersaturation in the Humboldt Current System. J. Geophys. Res. 123, 2018-2036 (2018).

24. Schneider, W. et al. Characteristics and formation of eastern South Pacific Intermediate Water. Geophy. Res. Lett. 30, 1581 (2003).

25. Fogel, M. L. \& Cifuentes, L. A. in Organic Geochemistry (eds Engel, M. H. \& Macko; S. A.) 73-98 (Plenum Press, 1993).

26. Druffel, E. R. M. et al. Penetration of anthropogenic carbon into organic particles of the deep ocean. Geophys. Res. Lett. 30, 1744-1748 (2003).

27. Pantoja, S., Sepúlveda, J. \& González, H. E. Decomposition of sinking proteinaceous material during fall in the oxygen minimum zone off northern Chile. Deep-Sea Res. I 51, 55-70 (2004).

28. Herrera, L. \& Escribano, R. Factors structuring the phytoplankton community in the upwelling site off El Loa River in northern Chile. J. Mar. Syst. 61, 13-38 (2006).

29. Hernández-Ayon, J. M. et al. Dynamics of the carbonate system across the peruvian oxygen minimum zone. Front. Mar. Sci. 6, 617 https://doi.org/ 10.3389/fmars.2019.00617 (2019)

30. Thamdrup, B., Dalsgaard, T. \& Revsbech, N. P. Widespread functional anoxia in the oxygen minimum zone of the eastern South Pacific. Deep Sea Res. I 65, 36-45 (2012)

31. Fiedler, P. C., Mendelssohn, R., Palacios, D. M. \& Bograd, S. J. Pycnocline variations in the Eastern Tropical and North Pacific, 1958-2008. J. Clim. 26, 583-599 (2013).

32. Franco, A. C. et al. Air-sea $\mathrm{CO}_{2}$ fluxes above the stratified oxygen minimum zone in the coastal region off Mexico. J. Geophys. Res. 119, 2923-2937 (2014).

33. Feely, R. A. et al. Evidence for upwelling of corrosive "acidified" water onto the continental shelf. Science 320, 1490-1492 (2008).

34. Hoffman, G. E. et al. High-frequency dynamics of ocean $\mathrm{pH}$ : a multiecosystem comparison. PLOS ONE 6, e28983 (2011).
35. Wang, Z. A. et al. The marine inorganic carbon system along the Gulf of Mexico and Atlantic coasts of the United States: Insights from a transregional coastal carbon study. Limnol. Oceanogr. 58, 325-342 (2013).

36. Hu, X. \& Cai, W.-J. An assessment of ocean margin anaerobic processes on oceanic alkalinity budget. Glob. Biogeochem. Cycles 25, GB3003 (2011).

37. Reinthaler, T., van Aken, H. M. \& Herndl, G. J. Major contribution of autotrophy to microbial carbon cycling in the deep North Atlantic's interior. Deep-Sea Res. II 57, 1572-1580 (2010).

38. Galán, A. et al. Temporal dynamics of nitrogen loss in the coastal upwelling ecosystem off central Chile: evidence of autotrophic denitrification through sulfide oxidation. Limnol. Oceanogr. 59, 1865-1878 (2014).

39. Callbeck, C. M. et al. Oxygen minimum zone cryptic sulfur cycling sustained by offshore transport of key sulfur oxidizing bacteria. Nat. Commun. 9, 1729 (2018).

40. Ruby, E. G., Holger, W. J. \& Deuser, W. G. Fractionation of stable carbon isotopes during chemoautotrophic growth of sulfur-oxidizing bacteria. Appl. Environ. Microbiol. 53, 1940-1943 (1987).

41. Löscher, C. R. et al. Water column biogeochemistry of oxygen minimum zones in the eastern tropical North Atlantic and eastern tropical South Pacific oceans. Biogeosciences 13, 3585-3606 (2016).

42. van Vliet, D. M. et al. The bacterial sulfur cycle in expanding dysoxic and euxinic marine waters. Environ. Microbiol. https://doi.org/10.1111/1462$2920.15265(2020)$

43. Wang, Y. et al. Impact of mesoscale eddies on chlorophyll variability off the coast of Chile. PLoS ONE 13, e0203598 (2018).

44. Schunck, H. et al. Giant hydrogen sulfide plume in the oxygen minimum zone off peru supports chemolithoautotrophy. PLoS ONE 8, e68661 (2013).

45. Chaigneau, A., Gizolme, A. \& Grados, C. Mesoscale eddies off Peru in altimeter records: Identification algorithms and eddy spatio-temporal patterns. Prog. Oceanogr. 79, 106-119 (2008).

46. Hamersley, M. R. et al. Anaerobic ammonium oxidation in the Peruvian oxygen minimum zone. Limnol. Oceanogr. 52, 923-933 (2007).

47. Kalvelage, T. et al. Oxygen sensitivity of anammox and coupled N-cycle processes in oxygen minimum zones. PLoS ONE 6, e29299 (2011).

48. Galán, A. et al. Anammox bacteria and the anaerobic oxidation of ammonium in the oxygen minimum zone off northern Chile. Deep-Sea Res. II 56, 1021-1031 (2009)

49. Dalsgaard, T. et al. Anammox and denitrification in the oxygen minimum zone of the eastern South Pacific. Limnol. Oceanogr. 57, 1331-1346 (2012).

50. Dalsgaard, T. et al. Oxygen at nanomolar levels reversibly suppresses process rates and gene expression in anammox and denitrification in the oxygen minimum zone off northern Chile. mBio 5, e01966-14 (2014).

51. Podlaska, A., Wakeham, S. G., Fanning, K. A. \& Taylor, G. T. Microbial community structure and productivity in the oxygen minimum zone of the eastern tropical North Pacific. Deep Sea Res. I 66, 77-89 (2012).

52. Cavan, E. et al. Remineralization of particulate organic carbon in an ocean oxygen minimum zone. Nat. Commun. 8, 14847 (2017).

53. Middelburg, J. J. Chemoautotrophy in the ocean. Geophys. Res. Lett. 38, L24604 (2011).

54. Könneke, M., Lipp, J. S. \& Hinrichs, K.-U. Carbon isotope fractionation by the marine ammonia-oxidizing archaeon Nitrosopumilus maritimus. Org. Geochem. 48, 21-24 (2012).

55. Molina, V. \& Farías, L. Aerobic ammonium oxidation in the oxycline and oxygen minimum zone of the eastern tropical South Pacific off northern Chile $\left(<20^{\circ} \mathrm{S}\right)$. Deep Sea Res. II 56, 1032-1041 (2009).

56. Lam, P. et al. Revising the nitrogen cycle in the Peruvian oxygen minimum zone. Proc. Natl Acad. Sci. USA 106, 4752-4757 (2009).

57. Bristow, L. A. et al. Ammonium and nitrite oxidation at nanomolar oxygen concentrations in oxygen minimum zone waters. Proc. Natl Acad. Sci. USA 113, 10601-10606 (2016).

58. Joye, S. B. et al. Oxidation of ammonia and methane in an alkaline, saline lake Limnol. Oceanogr. 44, 178-188 (1999).

59. Hulthe, G., Hulth, S. \& Hall, P. Effect of oxygen on degradation rate of refractory and labile organic matter in continental margin sediments. Geochim. Cosmoch. Acta 62, 1319-1328 (1998).

60. Kalvelage, T. et al. Nitrogen cycling driven by organic matter export in the South Pacific oxygen minimum zone. Nat. Geosci. 6, 228-234 (2013).

61. Kuenen, J. G. Anammox bacteria: from discovery to application. Nat. Rev. Microbiol. 6, 320-326 (2008).

62. Swan, B. K. et al. Potential for chemolithoautotrophy among ubiquitous bacteria lineages in the dark ocean. Science 333, 1296-1300 (2011).

63. Sheik, C. S., Jain, S. \& Dick, G. J. Metabolic flexibility of enigmatic SAR324 revealed through metagenomics and metatranscriptomics. Environ. Microbiol. 16, 304-317 (2014).

64. Thamdrup, B. et al. Anaerobic ammonium oxidation in the oxygen-deficient waters off northern Chile. Limnol. Oceanogr. 51, 2145-2156 (2006).

65. Lam, P. \& Kuypers, M. M. Microbial nitrogen cycling processes in oxygen minimum zones. Annu. Rev. Mar. Sci. 3, 317-345 (2011). 
66. Zehr, J. P. \& Kudela, R. M. Nitrogen cycle of the open ocean: from genes to ecosystems. Annu. Rev. Mar. Sci. 3, 197-225 (2011).

67. Pajares, M. S. \& Ramos, R. Processes and Microorganisms Involved in the Marine Nitrogen Cycle: Knowledge and Gaps. Front. Mar. Sci. 6, 739 (2019).

68. Smethie, J. R. \& William, M. Nutrient regeneration and denitrification in low oxygen fjords. Deep Sea Res. A: Oceanographic Res. Pap. 34, 983-1006 (1987).

69. Jensen, M. M., Kuypers, M. M., Lavik, G. \& Thamdrup, B. Rates and regulation of anaerobic ammonium oxidation and denitrification in the Black Sea. Limnol. Oceanogr. 53, 23-36 (2008).

70. Chang, B. X. et al. The effect of organic carbon on fixed nitrogen loss in the eastern tropical South Pacific and Arabian Sea oxygen deficient zones. Limnol. Oceanogr. 59, 1267-1274 (2014).

71. Guiñez, M., Valdéz, J. \& Sifeddine, A. Spatial and temporal variability of the sedimentary organic matter associated with the Oxygen Minimum Zone (OMZ) in a coastal environment of the northern Humboldt Currrent, Mejillones Bay, Chile. Lat. Am. J. Aquat. Res. 38, 242-253 (2010).

72. Matys, E. D. et al. Bacteriohopanepolyols along redox gradients in the Humboldt Current System off northern Chile. Geobiology 15, 844-857 (2017).

73. Rush, D. et al. Anaerobic ammonium-oxidizing bacteria: a biological source of the bacteriohopanetetrol stereoisomer in marine sediments. Geochim. Cosmochim. Acta 140, 50-64 (2014).

74. Cantarero, S. I. et al. Size-fractioned contribution of microbial biomass to suspended organic matter in the Eastern Tropical South Pacific Oxygen Minimum Zone. Front. Mar. Sci. 7, 540643 (2020).

75. Lengger et al. Dark carbon fixation in the Arabian Sea oxygen minimum zone contributes to sedimentary organic carbon (SOM). Glob. Biogeochem. Cycles 33, 1715-1732 (2019).

76. Marsay et al. Attenuation of sinking particulate organic carbon flux through the mesopelagic ocean. Proc. Natl Acad. Sci. USA 112, 1089-1094 (2015).

77. Meyer, K. M., Ridgwell, A. \& Payne, J. L. The influence of the biological pump on ocean chemistry: implications for long-term trends in marine redox chemistry, the global carbon cycle, and the evolution of marine animal ecosystems. Geobiology 14, 207-219 (2016).

78. Capone, D. G. \& Hutchins, D. A. Microbial biogeochemistry of coastal upwelling regimes in a changing ocean. Nat. Geosci. 6, 711-717 (2013)

79. Riquelme-Bugueño, R. et al. Diel vertical migration into anoxic and high$p \mathrm{CO}_{2}$ waters: acoustic and net-based krill observations in the Humboldt Current. Sci. Rep. 10, 17181 (2020).

80. Chen, A. et al. Deep oceans may acidify faster tan anticipated due to global warming. Nat. Clim. Change 7, 890-894 (2017).

81. Parsons, T. R., Maita, Y. \& Lalli, C. M. A Manual of Chemical and Biological Methods for Seawater Analysis 173 (Pergamon Press,1984).

82. Grasshoff, K., Kremling, K., \& Ehrhardt, M. Methods of Seawater Analysis 3rd edn (Wiley- VCH, 1999).

83. Gruber, N. \& Sarmiento, J. L. Global patterns of marine nitrogen fixation and denitrification. Glob. Biogeochem. Cycles 11, 235-266 (1997).

84. Dickson, A. G., Sabine, C. L. \& Christian, J. R. Guide to best practices for ocean $\mathrm{CO}_{2}$ measurements. PICES Spec. Publ. 3, 1-191 (2007).

85. Pierrot, D., Lewis, E. \& Wallace, D. W. R. in ORNL/CDIAC-105a (Carbon Dioxide Information Analysis Center, Oak Ridge National Laboratory, U.S. Department of Energy, 2006).

86. Mehrbach, C. et al. Measurement of the apparent dissociation constants of carbonic acid in seawater at atmospheric pressure. Limnol. Oceanogr. 18 897-907 (1973).

87. Dickson, A. G. \& Millero, F. J. A comparison of the equilibrium constants for the dissociation of carbonic acid in seawater media. Deep Sea Res. I 34, 1733-1743 (1987).

88. Dickson, A. G. Standard potential of the reaction: $\mathrm{AgCl}(\mathrm{s})+1.2 \mathrm{H}_{2}(\mathrm{~g})=\mathrm{Ag}(\mathrm{s})$ $+\mathrm{HCl}(\mathrm{aq})$, and the standard acidity constant of the ion $\mathrm{HSO}^{-4}$ in synthetic sea water from 273.15 to $318.15^{\circ} \mathrm{K}$. J. Chem. Thermodyn. 22, 113-127 (1990).

89. Torres, M. E., Mix, A. C. \& Rugh, W. D. Precise $\delta^{13} \mathrm{C}$ analysis of dissolved inorganic carbon in natural waters using automated headspace sampling and continuous-flow mass spectrometry. Limnol. Oceanogr. Methods 3, 349-360 (2005).

90. Rau, G. H., Riebesell, U. \& Wolf-Gladrow, D. A. A model of photosynthetic ${ }^{13} \mathrm{C}$ fractionation by marine phytoplankton based on diffusive molecular $\mathrm{CO}_{2}$ uptake. Mar. Ecol. Prog. Ser. 133, 275-285 (1996).
91. Popp, B. N. et al. Effect of phytoplankton cell geometry on carbon isotopic fractionation. Geochim. Cosmochim. Acta 62, 69-77 (1998).

92. Sakata, S. et al. Stable carbon-isotopic compositions of lipids isolated from the ammonia-oxidizing chemoautotroph Nitrosomonas europaea. Org. Geochem. 39, 1725-1734 (2008).

93. Garcia-Robledo et al. Cryptic oxygen cycling in anoxic marine zones. Proc. Natl. Acad. Sci. USA 114, 8319-8324 (2017).

\section{Acknowledgements}

This study was supported by ANID-Chile FONDECYT Grant 1170065 (CARbon Cycling and Physiological Traits in Phytoplankton Functional Groups under low pH/low OXygen conditions, CARpHOX) and by ANID—Chile National Competition for ship time (AUB 150006/12806 and AUB 170002). The Agencia Nacional de Investigacion y Desarrollo (ANID)-Millennium Science Initiative Program-Millennium Institute of Oceanography (IMO) ICN12_019 also supported a significant part of this work. Additional support from the Millennium Nucleus "Center for the Study of Multiple-Drivers on Marine Socio-Ecological Systems" (MUSELS) NC120069 funded by the Millennium Scientific Initiative (ANID) is also acknowledged. The FONDECYT Grant 1210171 also funded CAV during the last stage of this study. S.C. and J.S. acknowledge financial support from the Department of Geological Sciences and INSTAAR at the University of Colorado Boulder (CU Boulder).

\section{Author contributions}

All authors provided input into data availability and preliminary discussion. C.A.V. led the drafting of the text with major contributions in the same order from S.C., J.S, A.G., R.D.P., W.S., and secondarily from B.W., L.F., M.C.D., and J. Salisbury. C.A.V. carried out data analysis, figures from 1 to 5 , and main structure of the original version. S.C. carried out the carbon isotope mass balance model and prepared Fig. 6 and Tables 1 and 2 for results, wrote the text for the model section, and editions along the manuscript. B.D.W. and J.C.W. generated and helped interpret DIC $\delta^{13} \mathrm{C}$ data in 2015 . S.C., J.S., A.G., and R.D.P did a major contribution during the whole revision process.

\section{Competing interests}

The authors declare no competing interests.

\section{Additional information}

Supplementary information The online version contains supplementary material available at https://doi.org/10.1038/s41467-021-21871-4.

Correspondence and requests for materials should be addressed to C.A.V.

Peer review information Nature Communications thanks the anonymous reviewers for their contributions to the peer review of this work.

Reprints and permission information is available at http://www.nature.com/reprints

Publisher's note Springer Nature remains neutral with regard to jurisdictional claims in published maps and institutional affiliations.

Open Access This article is licensed under a Creative Commons Attribution 4.0 International License, which permits use, sharing, adaptation, distribution and reproduction in any medium or format, as long as you give appropriate credit to the original author(s) and the source, provide a link to the Creative Commons license, and indicate if changes were made. The images or other third party material in this article are included in the article's Creative Commons license, unless indicated otherwise in a credit line to the material. If material is not included in the article's Creative Commons license and your intended use is not permitted by statutory regulation or exceeds the permitted use, you will need to obtain permission directly from the copyright holder. To view a copy of this license, visit http://creativecommons.org/ licenses/by/4.0/

(C) The Author(s) 2021 